Prepared for the U.S. Department of Energy under Contract DE-AC05-76RL01830

\title{
Characteristics of KE Basin Sludge Samples Archived in the RPL - 2007
}

$\mathrm{CH}$ Delegard

AJ Schmidt

JW Chenault

November 2011

\section{Pacific Northwest}

NATIONAL LABORATORY

Proudly Operated by Battelle Since 1965 


\title{
DISCLAIMER
}

This report was prepared as an account of work sponsored by an agency of the United States Government. Neither the United States Government nor any agency thereof, nor Battelle Memorial Institute, nor any of their employees, makes any warranty, express or implied, or assumes any legal liability or responsibility for the accuracy, completeness, or usefulness of any information, apparatus, product, or process disclosed, or represents that its use would not infringe privately owned rights. Reference herein to any specific commercial product, process, or service by trade name, trademark, manufacturer, or otherwise does not necessarily constitute or imply its endorsement, recommendation, or favoring by the United States Government or any agency thereof, or Battelle Memorial Institute. The views and opinions of authors expressed herein do not necessarily state or reflect those of the United States Government or any agency thereof.

\author{
PACIFIC NORTHWEST NATIONAL LABORATORY \\ operated by \\ BATTELLE \\ for the \\ UNITED STATES DEPARTMENT OF ENERGY \\ under Contract DE-AC05-76RL01830
}

Printed in the United States of America
Available to DOE and DOE contractors from the Office of Scientific and Technical Information,
P.O. Box 62, Oak Ridge, TN 37831-0062;
ph: (865) 576-8401
fax: $(865) 576-5728$
email: reports@adonis.osti.gov

\begin{abstract}
Available to the public from the National Technical Information Service, U.S. Department of Commerce, 5285 Port Royal Rd., Springfield, VA 22161 ph: (800) 553-6847 fax: (703) 605-6900 email: orders@ntis.fedworld.gov

online ordering: http://www.ntis.gov/ordering.htm
\end{abstract}

This document was printed on recycled paper. 


\section{Characteristics of KE Basin Sludge Samples Archived in the RPL - 2007}

CH Delegard

AJ Schmidt

JW Chenault

November 2011

Prepared for

the U.S. Department of Energy

under Contract DE-AC05-76RL01830

Pacific Northwest National Laboratory

Richland, Washington 99352 



\section{Revision History}

\begin{tabular}{|c|c|l|}
\hline Revision & Date & \multicolumn{1}{c|}{ Reason for Revision } \\
\hline 0 & $\begin{array}{c}\text { November } \\
2007\end{array}$ & $\begin{array}{l}\text { Initial revision was issued to document a set of well-characterized } \\
\text { sludge samples that are suited to support evolving Sludge } \\
\text { Treatment Project initiatives. As a part of this effort, like samples } \\
\text { of KE Basin sludge were combined and transferred into new } \\
\text { containers and some of these samples were characterized to } \\
\text { determine the instances and degrees of change that have occurred } \\
\text { since their collection at the KE Basin by the K Basin Project. This } \\
\text { initial report was issued as a project letter, and the letter was } \\
\text { cleared for "limited distribution." }\end{array}$ \\
\hline 1 & November & $\begin{array}{l}\text { Revision 1 was issued to clear this report for "unlimited } \\
\text { distribution". Changes between Rev 0 and Rev were limited to } \\
\text { document formatting changes. }\end{array}$ \\
\hline 2011 & & \\
\hline
\end{tabular}





\section{Summary}

Samples of sludge were collected from the K East fuel storage basin (KE Basin) floor, contiguous pits (Weasel Pit, North Load Out Pit, Dummy Elevator Pit, and Tech View Pit), and fuel storage canisters between 1995 and 2003 for chemical and radionuclide concentration analysis, physical property determination, and chemical process testing work. Because of the value of the sludge in this testing and because of the cost of obtaining additional fresh samples, an ongoing program of sludge preservation has taken place with the goals to track the sludge identities and preserve, as well as possible, the sludge composition by keeping the sludge in sealed jars and maintaining water coverage on the sludge consistent with the controlling Fluor Hanford (FH) Sampling and Analysis plans and FH contracts with the Pacific Northwest National Laboratory (PNNL).

This work was originally initiated to provide material for planned hydrothermal treatment testing in accordance with the test plan for the Sludge Treatment Project (STP) corrosion process chemistry follow-on testing (Delegard et al. 2007a). Although most of the planned hydrothermal testing was cancelled in July 2007 (as described in the forward of Delegard et al. 2007b), sample consolidation and characterization was continued to identify a set of well-characterized sludge samples that are suited to support evolving STP initiatives. The work described in the letter was performed by the PNNL under the direction of the Sludge Treatment Project, managed by Fluor Hanford.

As described in this report, like samples of KE Basin sludge were combined and transferred into new containers and some of these samples were characterized to determine the instances and degrees of change that have occurred since their collection at the KE Basin by the K Basin Project. For a number of these samples, the physical properties (settled and particle densities and water and solids concentrations), the $\mathrm{pH}$, and the solid phases (crystalline phases as identified by X-ray diffractometry, XRD) also were determined and are reported. The results are compared with results, where available, found in prior testing and laboratory analyses.

Samples from similar origins were combined into new jars in the present work. Three consolidations of like samples were made: sample $\mathrm{KC}-2 / 3$ (a canister sludge composite) was created from nine assorted $\mathrm{KC}-2 / 3$ samples; KC-4 Whole (KE floor sludge collected from between canisters) was prepared from five KC-4 samples; and KC-6 (a KE floor sample composed largely of organic ion exchange resin) was prepared from two KC-6 samples. Composites of sludges from different sources also have been created over the past several years for various bench-scale property or process tests. Sludge composites present in usable form in the HLRF archives include 96-13 KE Comp A (a composite of KE canister sludge samples 96-01, 96-05, 96-06 L, 96-06 M/L, 96-08, 96-13, and 96-15), KE Floc Comp (from KE floor and pit sludge samples KC-4 M250, KC-5, and FE-5), KC Floor Comp (KE floor sludge samples KC-4 and KC-5), and KE Pit (from KE Weasel Pit samples KES-P-16, -Q-17, -R-18, -S-19, and -T-20). In the present work, KE Floc Comp sludge was gathered from samples present in two jars, one containing flocculating agent and a much smaller second sample containing no flocculating agent, to create a single item. The other composites, already in single jars, were transferred to new jars. Some individual samples were present in their original jars. Because glass becomes embrittled by extended exposure to high radiation fields, these samples were placed into new jars.

Results of the compositing and characterization are summarized in Table S.1 and show sludge sources, volumes, uranium concentrations, and settled densities. The settled densities of most of the recently measured key samples are within about $20 \%$ of their values measured just after sample collection. Also, as expected, settled sludge densities generally increase with uranium concentration while sludge $\mathrm{pH}$ generally decreases with increasing uranium concentration. It was also found that where prior data are available, the $\mathrm{pH}$ values in the present tests match the prior values within about $1 \mathrm{pH}$ unit. However, one sample, $\mathrm{KC}-4$ Whole, had much lower $\mathrm{pH}$ than what was measured initially. The XRD 
results (not given in Table S.1), where available, show disappearance of the uranium(IV) phases (various uraninites, $\mathrm{UO}_{2}, \mathrm{U}_{4} \mathrm{O}_{9}$, and $\mathrm{U}_{3} \mathrm{O}_{7}$ ) observed in the original samples to form uranium(VI) compounds including metaschoepite, becquerelite, and uranophane. Further details are provided in the report. 
Table S.1. Sources and Properties of Archived KE Basin Sludge Samples

\begin{tabular}{|c|c|c|c|c|c|c|c|}
\hline \multirow[b]{2}{*}{ Sample ID } & \multirow[b]{2}{*}{ Source } & \multirow{2}{*}{$\begin{array}{c}\text { Sample } \\
\text { Date }\end{array}$} & \multirow{2}{*}{$\begin{array}{c}\text { Stld. } \\
\text { Vol., ml }\end{array}$} & \multirow{2}{*}{$\begin{array}{c}\mathrm{U}], \\
\mathrm{dry} \\
\mathrm{wt} \%\end{array}$} & \multicolumn{2}{|c|}{ Stld. Density, g/cm $\mathrm{cm}^{3}$} & \multirow{2}{*}{ References } \\
\hline & & & & & Present & Original & \\
\hline $96-01$ & $\begin{array}{l}\text { Single closed-bottom canister with } \\
\text { good condition fuel }\end{array}$ & 8 Apr 96 & 15 & 0.0944 & 0.98 (cone) & $\begin{array}{c}2.09 \\
(1997)\end{array}$ & Makenas et al. 1997 \\
\hline $96-05$ & $\begin{array}{l}\text { Single closed-bottom canister with } \\
\text { very poor condition fuel }\end{array}$ & 9 Apr 96 & 80 & 58.5 & 1.77 (cone) & $\begin{array}{c}2.34 \\
(1997)\end{array}$ & Makenas et al. 1997 \\
\hline 96-08 SSOL & Single canister with poor condition fuel & $1 \begin{array}{c}10 \mathrm{Apr} \\
96\end{array}$ & 50 & 31.0 & - & $\begin{array}{c}1.19 \\
(1997)\end{array}$ & Makenas et al. 1997 \\
\hline 96-09 SSOL & Single empty open-bottom canister. & $\begin{array}{c}11 \mathrm{Apr} \\
96\end{array}$ & 50 & 13.1 & - & $\begin{array}{c}1.07 \\
(1997)\end{array}$ & Makenas et al. 1997 \\
\hline 96-11 SSOL & Single empty closed-bottom canister & $\begin{array}{l}12 \mathrm{Apr} \\
96\end{array}$ & $<50$ & 6.01 & - & $\begin{array}{l}1.23 \\
\text { (calc., } \\
1997)\end{array}$ & Makenas et al. 1997 \\
\hline $\begin{array}{c}96-13 \\
\text { (various) }\end{array}$ & $\begin{array}{l}\text { Single canister with poor condition fuel } \\
\text { (Settler Study, Solid Grad, SSOL) }\end{array}$ & $\begin{array}{c}18 \mathrm{Apr} \\
96\end{array}$ & $\begin{array}{c}125,100 \\
50\end{array}$ & 74.0 & - & $\begin{array}{c}2.458 \\
(1997)\end{array}$ & Makenas et al. 1997 \\
\hline $\begin{array}{c}\text { 96-13 } \\
\text { KE Comp A }\end{array}$ & $\begin{array}{l}\text { Composite of samples } 96-01,-05,-06, \\
-08,-13, \text { and }-15 \text { from single canisters } \\
\text { with good to very poor condition fuel }\end{array}$ & $\begin{array}{c}8-18 \\
\text { Apr } 96\end{array}$ & 125 & 52.1 & 1.90 (cone) & - & $\begin{array}{l}\text { Makenas et al. } 1997 ; \\
\text { Table } 3.2 \text { of Schmidt et al. } \\
1999\end{array}$ \\
\hline 96-15 SSOL & Single canister with poor condition fuel & $\begin{array}{c}18 \mathrm{Apr} \\
96\end{array}$ & 100 & 49.2 & - & $\begin{array}{c}1.845 \\
(1997) \\
\end{array}$ & Makenas et al. 1997 \\
\hline FE-5 & $\begin{array}{l}\text { Weasel pit including South Loadout Pit } \\
\text { sludge }\end{array}$ & $\begin{array}{c}26 \text { Apr } \\
\& 13 \\
\text { Jan } 99\end{array}$ & 260 & 5.32 & $\left|\begin{array}{c}1.66(\text { cone }) \\
1.68 \text { (jar) }\end{array}\right|$ & 1.50 & $\begin{array}{l}\text { Composite created in 222- } \\
\text { S Lab from KE-9 and KE- } \\
10 \text { single-pull samples; } \\
\text { Baker \& Welsh } 2001\end{array}$ \\
\hline KC-1 M500 & $\begin{array}{l}\text { Canister sludge from highly damaged } \\
\text { fuel collected from one sampling } \\
\text { location }\end{array}$ & $\begin{array}{l}12 \text { Apr } \\
99\end{array}$ & 20 & 68.6 & $\begin{array}{c}2.05 \text { (cone) } \\
2.66 \text { (jar) }\end{array}$ & 1.5 & $\begin{array}{l}\text { Sample passing } 500-\mu \mathrm{m} \\
\text { sieve; } 88.7 \text { wt } \% \text { of total } \\
\text { KC-1 wet solids; Baker \& } \\
\text { Welsh } 2001 ; \text { Bredt et al. } \\
\text { 1999; Bryan et al. } 2004\end{array}$ \\
\hline & $\begin{array}{l}\text { KC-2; consol. smpl. fr. fuel stor. can. } \\
\text { barrels w/ hi. dmgd. fuel fr. all } 3 \text { bays }\end{array}$ & \begin{tabular}{|c|}
$4-13$ \\
Mar 99 \\
\end{tabular} & 425 & 500 & 2.03 (cone) & 2.13 & $\begin{array}{l}\text { Composite KC-2/3 created } \\
\text { in } 325 \mathrm{Lab} ; \text { Baker \& }\end{array}$ \\
\hline $\mathrm{KC}-2 / 3$ & $\begin{array}{l}\text { KC-3; consol. smpl. fr. can. barrels } \\
\text { with mod. dmgd. fuel fr. all } 3 \text { bays }\end{array}$ & $\begin{array}{c}1-8 \mathrm{Apr} \\
99\end{array}$ & 425 & 59.0 & 2.14 (jar) & (1999) & $\begin{array}{l}\text { Welsh 2001; Bredt et al. } \\
1999\end{array}$ \\
\hline KC-4 Whole & Consol. smpl. fr. floor btwn. barrels of & $30-31$ & 120 & 166 & \begin{tabular}{|c|}
1.60 (cone) \\
1.56 (jar) \\
\end{tabular} & 1235 & Baker \& Welsh 2001; \\
\hline $\mathrm{KC}-4-2$ & $\begin{array}{l}\text { open bot. can. W/ highly dmgd. fuel fr. } \\
\text { all } 3 \text { bays }\end{array}$ & Mar 99 & 165 & 10.6 & \begin{tabular}{|c|}
1.53 (cone) \\
1.60 (jar)
\end{tabular} & 1.235 & Bredt et al. 1999 \\
\hline $\mathrm{KC}-6$ & $\begin{array}{l}\text { Consol. smpl. fr. floor area in west bay } \\
\text { known to be v. high in ion exchange }\end{array}$ & $13 \& 26$ & 140 & 0.314 & $\begin{array}{c}1.31 \text { (cone) } \\
1.20 \text { (jar) } \\
\end{array}$ & 1.1 & $\begin{array}{l}\text { Baker \& Welsh 2001; } \\
\text { Bredt et al. 1999; Bryan et }\end{array}$ \\
\hline KC-6 carboy & beads & & 6400 & & - & & al. 2004 \\
\hline $\begin{array}{l}\text { KC Floor } \\
\text { Comp }\end{array}$ & $\begin{array}{l}\text { Comp. of } 40 \text { vol\% KC-4 \& } 60 \text { vol\% } \\
\text { KC-5 (stl. sl.); KC-5 consol. deep sl. fr. } \\
\text { all } 3 \text { bays (smpl. } 29 \text { Mar 99) }\end{array}$ & $\begin{array}{c}29-31 \\
\text { Mar } 99\end{array}$ & 25 & 10.3 & $\begin{array}{c}1.20 \text { (cone) } \\
1.34 \text { (jar) }\end{array} \mid$ & $\begin{array}{l}1.21 \\
(\text { calc., } \\
2000)\end{array}$ & $\begin{array}{l}\text { Baker \& Welsh 2001; } \\
\text { Silvers et al. } 2000\end{array}$ \\
\hline $\begin{array}{l}\text { KE Container } \\
\text { Comp \& } \\
\text { Floc }^{(a)}\end{array}$ & $\begin{array}{l}\text { Composite of KC-2/3, KC-4, KC-5 } \\
\text { P250 \& FE-5 }\end{array}$ & $\begin{array}{c}13 \text { Jan }- \\
26 \text { Apr } \\
99\end{array}$ & 25,10 & 15.7 & - & $\begin{array}{l}1.65,1.53 \\
\quad \text { cone }) \\
1.54,1.45 \\
\quad \text { (jar) }\end{array}$ & Delegard et al. 2007a \\
\hline $\begin{array}{l}\text { KE Floc } \\
\text { Comp }\end{array}$ & $\begin{array}{l}\text { Composite of KC-4 M250, KC-5, FE- } \\
5 \text {, and KC Can Comp }\end{array}$ & $\begin{array}{c}13 \text { Jan }- \\
26 \text { Apr } \\
99\end{array}$ & 260 & 10.3 & $\left|\begin{array}{c}1.25 \text { (cone) } \\
1.30 \text { (jar) }\end{array}\right|$ & $\begin{array}{l}1.25 \\
(2004)\end{array}$ & $\begin{array}{l}\text { Baker \& Welsh 2001; } \\
\text { Schmidt et al. } 2004\end{array}$ \\
\hline KE NLOP & $\begin{array}{l}\text { KE North Load Out Pit; top-to-bottom } \\
\text { sample composite present in three jars } \\
(\# 1, \# 2 \text {, and } \# 3)\end{array}$ & $\begin{array}{c}13 \& 19 \\
\text { Dec } 03\end{array} \mid$ & 645 & 2.51 & 1.06 (cone) & $\begin{array}{l}1.23 \\
(2004)\end{array}$ & $\begin{array}{l}\text { Mellinger et al. 2004; } \\
\text { Shelor et al. } 2004\end{array}$ \\
\hline KE Pit & $\begin{array}{l}\text { Weasel Pit composite of KES-P-16, - } \\
\text { Q-17, -R-18, -S-19, \& -T-20 }\end{array}$ & $\begin{array}{c}15-25 \\
\text { Sep } 95\end{array}$ & 125 & 7.99 & $\begin{array}{c}1.77 \text { (cone) } \\
1.92 \text { (jar) }\end{array} \mid$ & - & $\begin{array}{l}\text { Makenas et al. 1996; dry } \\
\text { smpls. weigh \& mix w/ } \\
\mathrm{H}_{2} \mathrm{O} \text {, Carlson et al. } 1998\end{array}$ \\
\hline
\end{tabular}





\section{Contents}

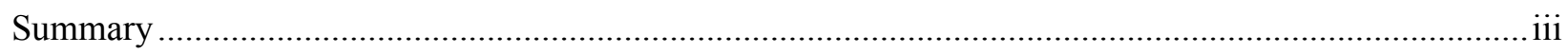

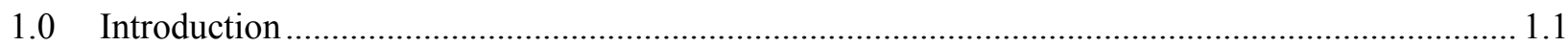

2.0 Sludge Storage Conditions in the RPL and Rationale for Gathering Similar Sludge Samples........ 2.1

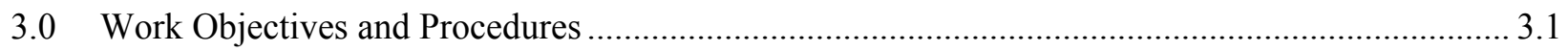

4.0 Compositing Strategy and Constituent Sludge Descriptions ........................................................ 4.1

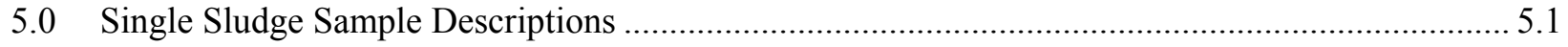

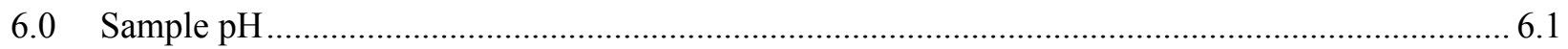

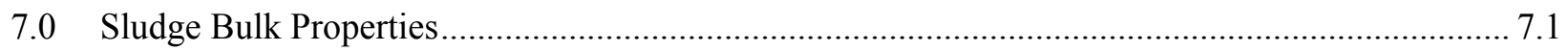

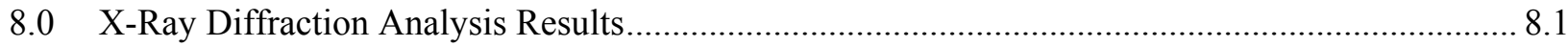

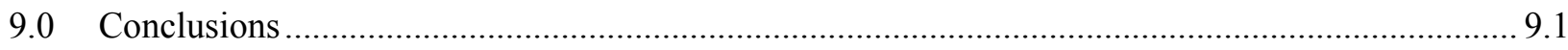

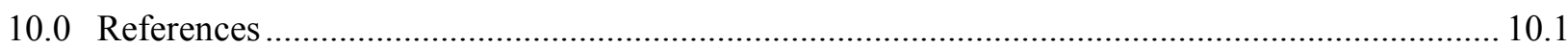

Appendix A Sludge Sample Uses for Characterization and Process Testing ...................................... A.1

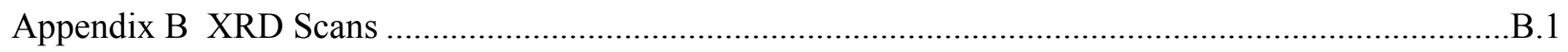

\section{Figures}

6.1. Sludge $\mathrm{pH}$ as a Function of Dry-Basis Uranium Concentration .................................................. 6.2

7.1. Sludge Density as a Function of Dry-Basis Uranium Concentration............................................ 7.1

\section{Tables}

S.1. Sources and Properties of Archived KE Basin Sludge Samples ...................................................

8.1. Sludge Archive Samples for Compositing, Re-Jarring, Blending, and Inventory ........................ 8.3

8.2. Source Information for Archived KE Basin Sludge Samples ..................................................... 8.4

8.3. Chemical and Radiochemical Compositions of Archive Sludge Analyzed for Bulk Properties...... 8.5

8.4. Chemical and Radiochemical Compositions for Archive Sludges That Were Not Re-Jarred ......... 8.7

8.5. Bulk Physical Properties and $\mathrm{pH}$ of Agitated Sludge ................................................................ 8.8

8.6. Summary of XRD Findings for Archived Sludge Samples ..................................................... 8.9

9.1. Sources and Properties of Archived KE Basin Sludge Samples ................................................. 9.2 



\subsection{Introduction}

Samples of sludge were collected from the K East fuel storage basin (KE Basin) floor, contiguous pits (Weasel Pit, Load Out Pits), and fuel storage canisters between 1995 and 2003 for chemical and radionuclide concentration analysis, physical property determination, and chemical process testing work. Since their collection, the samples have been stored at hot cell temperatures $\left(\sim 30^{\circ} \mathrm{C}\right)$ or room temperature $\left(\sim 20^{\circ} \mathrm{C}\right.$, for KE North Loadout Pit, KE NLOP, only). The sludge samples have continued to be of use in the intervening years as methods to process the sludge have been developed and tested and additional information on their properties and chemical reactions is required (Appendix A).

This work was originally initiated to provide material for planned hydrothermal treatment testing in accordance with the test plan for the Sludge Treatment Project (STP) corrosion process chemistry follow-on testing (Delegard et al. 2007a). Although most of the planned hydrothermal testing was cancelled in July 2007 (as described in the forward of Delegard et al. 2007b), sample consolidation and characterization was continued to identify the broad set well-characterized sludge samples that are suited to support evolving STP initiatives. The work described in the letter was performed by the PNNL under the direction of the Sludge Treatment Project, managed by Fluor Hanford.

Because of the value of the sludge in this testing and because of the cost of obtaining additional fresh samples, an ongoing program of sludge preservation has taken place with the goals to track the sludge identities and preserve, as well as possible, the sludge composition by keeping the sludge in sealed jars and maintaining water coverage on the sludge. Even with this active care, it is certain that the uranium metal within the sludge samples has continued to oxidize to $\mathrm{UO}_{2}$. Further, the product $\mathrm{UO}_{2}$ plus other $\mathrm{U}(\mathrm{IV})$ oxide (such as uraninite, $\mathrm{UO}_{2 . \mathrm{x}}$, where $\mathrm{x}$ ranges from 0 to 0.33 ) within the sludge samples likely have continued to air-oxidize to form U(VI) oxyhydroxides (such as metaschoepite, $\mathrm{UO}_{3} \cdot 2 \mathrm{H}_{2} \mathrm{O}$ ) and more mineralized phases such as becquerelite, soddyite, and uranophane, among others. ${ }^{(1)}$ In addition, iron and perhaps aluminum hydroxides $\left[\mathrm{Fe}(\mathrm{OH})_{3}\right.$ and $\left.\mathrm{Al}(\mathrm{OH})_{3}\right]$ may have continued to dehydrate to form oxyhydroxides (e.g., FeOOH and $\mathrm{AlOOH}$ ) during the storage, despite occasional water replenishment, due to natural tendencies to chemical equilibrium.

At the same time, sludge in the KE Basin itself has undergone aggressive agitation, mixing, and aeration in sludge transfer and containerization operations at $\sim 12^{\circ} \mathrm{C}$. Therefore, both the sludge present at the K Basins and the sludge samples archived within hot cell and laboratory storage have been altered since sampling and are tending to the same state of oxidation and dehydration, though potentially at different rates. With time, sludge from both sources would proceed to complete equilibrium by oxidation, mineralization, and dehydration reactions.

The sludge samples have been kept in closed and labeled jars and the jar contents monitored periodically to ensure that the sludges are wetted with visible supernatant water. Water levels have been maintained, though not without fail, using either distilled deionized (DI) water or, if possible, with K Basin water also kept in archive in the Radiochemical Processing Laboratory, RPL. Most of the sludge samples have been handled and archived in shielded radiochemical facilities (hot cells). However, because of their low contained radionuclide content, the KE NLOP sludges were received and tested in a room-temperature glovebox for initial characterization in 2003. Once the characterization was completed, the remaining KE NLOP sludge was transferred to a sample storage room in the RPL basement. The KE NLOP samples were stored in the basement $\left(\sim 20^{\circ} \mathrm{C}\right)$ from the summer of 2003 until they were transferred

(1) Becquerelite is $\mathrm{Ca}\left(\mathrm{UO}_{2}\right)_{6} \mathrm{O}_{4}(\mathrm{OH})_{6}\left(\mathrm{H}_{2} \mathrm{O}\right)_{8}$, soddyite is $\left(\mathrm{UO}_{2}\right)_{2} \mathrm{SiO}_{4} \cdot 2 \mathrm{H}_{2} \mathrm{O}$, and uranophane is $\mathrm{Ca}\left(\mathrm{UO}_{2}\right)_{2}\left(\mathrm{SiO}_{3} \mathrm{OH}\right)_{2} \cdot 5 \mathrm{H}_{2} \mathrm{O}$. 
to hot cell storage in the High-Level Radiochemistry Facility, HLRF, of the RPL during the summer of 2007.

The objectives of the work described in this report were to collect and consolidate like samples of KE Basin sludge into new containers and to characterize some of the sludge to determine the instances and degrees of change that have occurred since their collection. The quantities and properties of the archived sludge materials are described. The physical properties (bulk and particle density and water and solids concentrations), the $\mathrm{pH}$, and the solid phases present in a number of these samples also were determined and are reported. The results are compared with results, where available, found in prior testing. 


\subsection{Sludge Storage Conditions in the RPL and Rationale for Gathering Similar Sludge Samples}

Base chemical and radiochemical analyses have been performed on all of the sludge samples currently archived in the RPL. Since characterization, some of the sludge samples have been kept in reserve without perturbation for additional characterization or process testing. Gas generation testing at hot cell temperatures also was performed to monitor changes to the sludge (e.g., uranium metal corrosion) that would have occurred at the same rate, without monitoring, in storage. ${ }^{(1)}$ Other tests having negligible impact on sludge properties compared with ordinary hot cell storage included thermal conductivity and shear strength measurements (Poloski et al. 2002) and long-term ( 2.4-year) settling/consolidation and water evaporation rate tests run for sub-samples of FE-5, KC-2/3, KC-4, KC-5, and 96-13 (Delegard et al. 2005). Other sludge sub-samples were sieved and the sieve fractions weighed and stored separately (e.g., Bredt et al. 1999). Because these sludges were generally kept wetted (except as noted) and thus under conditions that they would otherwise have experienced as archive material, they were not physically or chemically altered by virtue of the characterization testing or by dry-out. However, like the undisturbed archive samples, they were not kept under anoxic conditions (except for the relatively short-term gas generation test materials) and therefore may have been susceptible to oxidation by air. Sub-samples that were judged not to have been altered by testing could be candidates for consolidation with other intact sludge sub-samples from the same source which had been held in archive.

To simplify storage and maintenance, gather like materials in a single container for better inventory, and make more durable by replacing the original glass containers that can become embrittled by irradiation, samples from similar origins therefore were combined into new jars in the present work. Three such consolidations of like samples were made - sample KC-2/3 Comp was created from nine assorted $\mathrm{KC}-2 / 3$ samples, $\mathrm{KC}-4$ Whole was prepared from five $\mathrm{KC}-4$ samples, and $\mathrm{KC}-6$ was prepared from two KC-6 samples.

Composites of sludges from different sources also have been created over the past several years for various bench-scale property or process tests. The sludge composites present in usable form in the HLRF archives include 96-13 KE Comp A (a composite of 96-01, 96-05, 96-06 L, 96-06 M/L, 96-08, 96-13, and 96-15 samples), KE Floc Comp (from KC-4 M250, KC-5, and FE-5 samples), KC Floor Comp (from KC-4 and KC-5 samples), and KE Pit (from KES-P-16, -Q-17, -R-18, -S-19, and -T-20). In the present work, KE Floc Comp sludge was gathered from samples present in two jars, one containing flocculating agent, the other containing no flocculating agent, to create a single item. The other composites, already in single jars, were transferred to new jars.

Some individual samples were present in their original jars. Again, because glass becomes embrittled by extended exposure to high radiation fields, these samples were placed into new jars. The individual samples that were re-jarred include KC-1 M500 and KC-4-L Dup (which was renamed KC-4-2).

Sludge samples in quantities attractive for future testing also have recently been transferred into new individual jars and transferred from the Shielded Analytical Laboratory (SAL) of the RPL to the HLRF. These samples include 96-01, 96-05, 96-08 SSOL, 96-09 SSOL, three 96-13 samples (Settler Study, Solid Grad, and SSOL), and 96-15 SSOL. The term SSOL means settled solids.

(1) Some of the characterization testing would have altered the sludge composition. For example, gas generation testing performed at elevated temperatures (Delegard et al. 2000, Bryan et al. 2004) would accelerate or even alter the aging that otherwise might occur at hot cell temperature. 



\subsection{Work Objectives and Procedures}

Aside from retrieval of the KE NLOP sludge from archive storage in the RPL basement, retrieval of other samples from the SAL, and preparation of sample containers, the work activities occurred in the HLRF. The testing was performed under a Test Instruction approved by the Fluor Hanford KBC/STP Project and PNNL project manager, scientists, shielded facility management, quality engineering, and hot cell operations ${ }^{(1)}$ under the existing RPL research operation procedure. ${ }^{(2)}$ Existing operation-specific procedures for hot cell operations were also used in performing this work.

The objectives of the work were to gather and simplify the KE Basin sludge inventory, to replace the potentially embrittled old glass jars with new glass jars, to mechanically blend the sludge to decrease self-cementation and improve contact with water, to determine the quantities of usable sludge available for future testing, and to characterize the sludge by its physical properties (bulk and particle density, water and solids concentration) and $\mathrm{pH}$. Selected sludge samples also were taken for analysis of their contained crystalline phases using X-ray diffractometry (XRD). The samples were prepared ${ }^{(3)}$ and the XRD scans gathered $^{(4)}$ according to existing RPL procedures.

Combining sub-samples arising from common sources was done to achieve the goals of simplifying the sample management and maintenance, gathering sufficient materials for future characterization or process testing, and removing sub-samples from storage that did not contain retrievable quantities or were dried out or otherwise compromised. The high radiation fields within the hot cells and from the sludges themselves cause the glass containers and the plastic lids to weaken and become brittle and identification markings to fade or flake off the containers. Therefore, another goal of the sludge sample management was to place samples in new and more durable labeled jars. The re-jarring was done for samples that were recombined but also for single, large quantity, samples being kept in old or degraded containers. Samples recently (2007) placed in new jars were not repackaged.

Once the sludges were recombined, simply re-jarred, or gathered, water was added, if needed, and the sludge materials were blended using an overhead electric drink mixer (3.6-cm diameter blade turning at $\sim 720$ RPM to give $\sim 140 \mathrm{~cm} / \mathrm{sec}$ tip speed). The time of blending varied according to the goals of breaking agglomerates and re-suspending the sludge solids in water but not going beyond this degree of agitation. Blending times did not exceed four minutes for any sludge and blending was not necessary for some sludges.

(1) Delegard CH. 2007. Re-Jarring and Preparation of K East Basin Sludge Composites from Archived Samples, Test Instruction 53451 TI01, Rev. 0, Pacific Northwest National Laboratory, Richland, WA.

(2) RPL Independent Review Committee. 2007. PNNL Operating Procedure, Routine Research Operations, RPL-OP-001, Rev. 5, Pacific Northwest National Laboratory, Richland, WA.

(3) Scheele RD and CH Delegard. 2005. Preparing Sealed Radioactive Samples for XRD and Other Purposes, RPL-PIP-4, Pacific Northwest National Laboratory, Richland, WA.

(4) Schaef, HT. 2004. Operation of Scintag Pad-V X-Ray Diffractometer, RPL-XRD-PIP, Pacific Northwest National Laboratory, Richland, WA. 



\subsection{Compositing Strategy and Constituent Sludge Descriptions}

The sludges selected for compositing and re-jarring were KC-2/3, KC-4, KC-6, and KE Floc Comp. The rationales for their compositing are provided in the following respective sections. The qualities and quantities of the constituent sub-samples used in the compositing are given in Table 8.1. The sources and properties of the sludges are described in the following narrative and summarized in Table 8.2.

\section{KC-2/3 Comp}

The sub-samples from KC-2/3 were gathered with the objective to form a single composite representative of the original $\mathrm{KC}-2 / 3$ sample. The contents of ten sample jars from nine different labeled designations were collected. The samples KC-2/3 Settling Study, KC-2/3 Whole, KC-2/3 SS, and KC-2 $\mathrm{SSOL}$ include the entire particle size distribution of the $\mathrm{KC}-2 / 3$ sludge sample. Based on prior studies of $\mathrm{KC}-2 / 3$ sludge, $\sim 70 \mathrm{wt} \%$ of the settled $\mathrm{KC}-2 / 3$ sludge is derived from $\mathrm{KC}-2$ (Bredt et al. 1999). Therefore, sample KC-2 SSOL from KC-2 well represents $\mathrm{KC}-2 / 3$. The $\mathrm{KC}-2 / 3$ sludge was sieved into fractions passing and retained on a $250-\mu \mathrm{m}$ sieve (M250, meaning minus $250 \mu \mathrm{m}$, and P250, or plus $250 \mu \mathrm{m}$, respectively, in prior operations). When combining the sub-samples KC-2/3 M250 ( 40 ml), another KC-2/3 M250 ( $70 \mathrm{ml})$, and KC-3 + KC-2 Rec $2(40 \mathrm{ml})$ with KC-2/3 P250 (25 ml), a total of $175 \mathrm{ml}$ of sludge were obtained, of which $\sim 86 \mathrm{vol} \%$ is in the M250 fraction. This distribution is near that of the original KC-2/3 sludge in which about $78 \mathrm{wt} \%$ (wet) passed the $250-\mu \mathrm{m}$ sieve given that the M250 $\left(2.129 \mathrm{~g} / \mathrm{cm}^{3}\right)$ and P250 (2.109 $\left.\mathrm{g} / \mathrm{cm}^{3}\right)$ fractions had similar densities (Bredt et al. 1999).

The sample $\mathrm{KC}-2 / 3$ is itself a composite of consolidated samples taken from canister barrels containing highly damaged fuel (sample KC-2) and moderately damaged fuel (sample KC-3) from all three KE Basin bays (Baker and Welsh 2001). The composite was prepared in the 325 Laboratory shortly after the KC-2 and KC-3 samples were received. The dry-basis composition of the KC-2/3 sludge given in Table 8.3 (Baker and Welsh 2001) shows that the sludge contains relatively high uranium concentration $(59.0 \mathrm{wt} \%$, dry basis).

\section{KC-4 Whole}

The sub-samples KC-4 (labeled KC-4 on the jar body but with a lid labeled KC-5), KC-4 LPG, KC-4 Dup LPG, and KC-4 include the entire sludge particle size distribution. The sub-sample KC-4 Rec contains only sludge passing a $250-\mu \mathrm{m}$ sieve. However, since $90 \mathrm{wt} \%$ of the sludge is in the M250 fraction (Bredt et al. 1999), inclusion of this sub-sample has little impact on the composite composition. These five samples were combined to make the KC-4 composite, $\mathrm{KC}-4$ Whole. The KC-4 sludge was a consolidated sample taken from between barrels of open-bottom canisters containing highly damaged fuel from all three KE Basin bays (Baker and Welsh 2001). The dry-basis composition of KC-4 presented in Table 8.3 (Baker and Welsh 2001) shows that the sludge contains $16.6 \mathrm{wt} \%$ uranium on a dry basis. In contrast to the behaviors of other sludge samples, this composite has a slimy consistency, did not settle well, and the supernatant liquid remained turbid. Also, the sludge $\mathrm{pH}$, as will be seen, was uncharacteristically low.

KC-6

Only two sub-samples, KC-6 and KC-6 SSOL A, are combined to make the KC-6 composite. This material was taken from an area of the floor in the KE Basin west bay known to be high in ion exchange resin beads (Baker and Welsh 2001). The sample KC-6 was not analyzed. The composition presented in 
Table 8.3 for KC-6 is that reported for the similar sample, KES-H-08 (Makenas et al. 1996) collected from the same KE floor location. The dry-basis uranium concentration in this sludge is low, $\sim 0.3 \mathrm{wt} \%$.

\section{KE Floc Comp}

The sub-sample KE Floc Comp (feed) was used as the source material for KE Basin sludge flocculent testing (Schmidt et al. 2004). The sub-sample KE Floc Sludge was the same as KE Floc Comp (feed) but also contained Nalco 7194 Plus flocculating agent. The KE Floc Comp feed sludge contained KC-4 M250 sludge (50.6 wt \%, settled basis), KC-5 sludge (29.6 wt\%), and FE-5 sludge (19.4 wt\%) with a very small quantity $(0.35 \mathrm{wt} \%)$ of a combined set of canister sludge samples (Schmidt et al. 2004). Combining the flocculated $(\sim 200 \mathrm{ml})$ and non-flocculated $(\sim 70 \mathrm{ml})$ portions provides a larger volume of sludge of known composition in a form suitable for subsequent testing.

The sample KC-4 M250 comprises $90.2 \mathrm{wt} \%$ of the total settled KC-4 sludge (Table 6, Bredt et al. 1999) so the KC-4 M250 composition, which was not analyzed, may be represented by that of KC-4 itself. As noted above, $\mathrm{KC}-4$ and $\mathrm{KC}-5$ arose, respectively, from the floor between barrels of open bottom canisters and from areas of deep sludge in the KE Basin (Baker and Welsh 2001). The FE-5 sludge was a single-pull sample taken from the Weasel Pit and also contains South Loadout Pit sludge (Baker and Welsh 2001). The compositions of the individual KC-4 M250 (represented by KC-4), KC-5, and FE-5 portions were combined to determine the composition of the KE Floc Comp sample reported in Table 8.3. Because of its low $(0.35 \mathrm{wt} \%$, settled basis) concentration, the contribution of the combined canister sludge was not accounted. Based on these calculations, the KE Floc Comp sludge contains approximately $10 \mathrm{wt} \%$ uranium on a dry basis. 


\subsection{Single Sludge Sample Descriptions}

The qualities and quantities of single samples that were re-jarred (KC-1 M500, FE-5 Comp 1, KC-4-2, KC Floor Comp, KE Pit, and 96-11 SSOL), the samples in new jars from SAL that were only blended (96-01, 96-05, and 96-13 KE Comp A), samples from SAL that were not blended (96-08 SSOL, 96-09 SSOL, the 96-13 samples Settling Study, Solid Grad, and SSOL, and 96-15 SSOL), the two KE NLOP samples, KE NLOP Jar \#1 and Jar \#3 (which had been stored in the RPL basement, transferred to the HLRF, and opened for sampling; Jar \#2 also was transferred to the HLRF but was not opened), and the samples that were already in the HLRF and were not re-jarred or blended (KC-6 in the carboy and KE Container and KE Container Comp Floc) are shown in Table 8.1. The sources and properties of the sludges are described in the following narrative and summarized in Table 8.2.

96-01

Sample 96-01 was taken from a stainless steel canister containing fuel in relatively good condition. This sludge was agitated and sampled for bulk and $\mathrm{pH}$ analyses. In May 2007, this sample was placed into a new jar in SAL. Chemical concentrations for potassium, chromium, nickel, sodium, and uranium obtained in the analysis of this sludge are of doubtful quality and the plutonium and americium values also appear to be anomalously low. As will be seen, five different uranium concentration values were reported, ranging from $<0.02 \mathrm{wt} \%$ to over $80 \mathrm{wt} \%$ (Makenas et al. 1997). The analytical results are provided in Table 8.3 for completeness but are not reliable for the named analytes.

96-05

Sample 96-05 is $58.5 \mathrm{wt} \%$ uranium (dry basis) and was taken from a stainless steel canister containing fuel observed to be in very poor condition (Makenas et al. 1997). In May 2007, this sample was placed into a new jar in SAL and then transferred to the HLRF where it was agitated and sampled. The analytical results are shown in Table 8.3.

\section{6-08 SSOL}

Sample 96-08 SSOL is moderately high in uranium concentration ( $31.0 \mathrm{wt} \%$, dry basis) and was taken from an aluminum canister containing fuel observed to be in poor condition (Makenas et al. 1997). In May 2007, this sample was placed into a new jar in SAL. The sample was not agitated in the present testing. The analytical results are given in Table 8.4.

\section{6-09 SSOL}

Sample 96-09 SSOL is relatively low in uranium concentration (13.1 wt $\%$, dry basis) and was taken from an aluminum canister containing fuel of unknown condition (Makenas et al. 1997). The sample was not re-jarred or agitated in the present testing. The analytical results are reported in Table 8.4.

\section{6-11 SSOL}

Sample 96-11 SSOL is a settled solids portion of sample 96-11, taken from an empty stainless steel canister (Makenas et al. 1997). Accordingly, the uranium concentration is relatively low ( $\sim 6 \mathrm{wt} \%$, dry basis) for a canister sludge. The sample 96-11 was divided into upper (96-11 U) and lower (96-11 L) portions before the portions were individually analyzed (Makenas et al. 1997). The upper portion comprised 7 volume $\%$ and the lower 93 volume $\%$ of the total sludge. The compositions of the individual portions were combined to determine the composition of the total 96-11 sample reported in Table 8.4. In 
May 2007, this sample was placed into a new jar in SAL, and then transferred to HLRF, but was not agitated in the present testing.

\section{6-13 Settling Study, Solid Grad, and SSOL}

Sample 96-13 is available in three jars (labeled Settling Study, Solid Grad, and SSOL) and is high in uranium concentration ( $74.0 \mathrm{wt} \%$, dry basis). The sample was taken from an aluminum canister containing poor condition fuel (Makenas et al. 1997). None of the three samples was re-jarred or blended in the present testing. The sample analyses are summarized in Table 8.4.

Sample "96-13 Solid Grad" was collected after completion of a multi-year settling test (Delegard et al. 2005). In this test, $\sim 100 \mathrm{ml}$ aliquots of various sludge samples were placed into capped 250-ml graduated cylinders with excess water and their settled volumes were monitored with time to look for evidence of long-term compaction. At the completion of the testing, all other sludge samples were readily slurried and poured from their respective graduated cylinders into sample jars. However, the 96-13 sample self-cemented and could only be recovered by breaking the graduated cylinder. For this reason, a sample of the agglomerated "96-13 Solid Grad" recovered from the settling test, was included in the present study for XRD analysis.

\section{6-13 KE Comp A}

The sample 96-13 KE Comp A contains sludge from sample 96-13 but also contains other canister sludges. It is a composite prepared from canister sludge samples 96-01 (61.92 g), 96-05 (62.92 g), 96-06 L (74.05 g), 96-06 M/L (57.37 g), 96-08 (39.03 g), 96-13 (124.54 g), and 96-15 (57.37 g). The first two were from stainless steel canisters and the others from aluminum canisters. The sludges, which were composited for bench-scale validation testing of nitric acid dissolution processing, were dry before their compositing and the noted weights are their dry weights (Schmidt et al. 1999). The composite sludge is called "KE Canister Sludge Composite" in Schmidt et al. (1999) and its previously analyzed composition is given in a footnote to Table 8.3 in the present report.

The sample 96-06 was split into 96-06 $\mathrm{M}$ and 96-06 L fractions (representing 53 and $47 \mathrm{vol} \%$, respectively, of the total settled 96-06 sample) before analyses of the individual fractions. The individual 96-06 $\mathrm{M}$ and 96-06 L sludge compositions (Makenas et al. 1997) then were combined to determine the composition of the total $96-06 \mathrm{M} / \mathrm{L}$ portion contributing to the $96-13 \mathrm{KE}$ Comp A composite. The compositions of the seven sludge constituents were combined in a similar manner (including those of 96-01, which contains many concentration values of suspect quality) to calculate the composition of the 96-13 KE Comp A provided in the body of Table 8.3. The dry-basis uranium concentration is $52.1 \mathrm{wt} \%$. This composite was re-jarred, sampled, and agitated in the present testing.

\section{6-15 SSOL}

Sample $96-15$ is moderately high in uranium concentration ( $49.2 \mathrm{wt} \%$, dry basis). The sample was taken from an aluminum canister containing poor condition fuel (Makenas et al. 1997). In May 2007, this sample was placed into a new jar in SAL. The sample analytical results are given in Table 8.4.

\section{FE-5 Comp 1}

The sample FE-5 Comp 1 is from sample FE-5, itself a composite prepared in the 222-S Laboratory from the KE-9 and KE-10 samples drawn from the KE Weasel Pit and which also includes South Loadout Pit sludge (Baker and Welsh 2001). Its composition (Baker and Welsh 2001) shows it to be relatively low (5.32 wt\%, dry basis) in uranium concentration (Table 8.3). This sample was re-jarred and agitated. 


\section{KC-1 M500}

The sample $\mathrm{KC}-1 \mathrm{M} 500$ is the portion of the $\mathrm{KC}-1$ sample that was retained on $500-\mu \mathrm{m}$ and larger sieves during sieve analyses (Bredt et al. 1999). The M500 fraction comprises $88.1 \mathrm{wt} \%$ of the total $\mathrm{KC}-1$ wet (settled) solids. Therefore, the assumed composition of KC-1 M500 is that of non-fractionated $\mathrm{KC}-1$ (given in Table 8.3). The sample $\mathrm{KC}-1$ is a canister sludge taken from an area with highly damaged fuel (Baker and Welsh 2001). The dry-basis uranium concentration is $68.6 \mathrm{wt} \%$. This sample was re-jarred and agitated.

\section{KC-4-2}

The sample KC-4-2 is taken from KC-4 and thus is nominally the same as that of KC-4 Whole presented in Table 8.3. The KC-4 sample, $16.6 \mathrm{wt} \%$ uranium (dry basis), was obtained between barrels of open-bottomed canisters containing highly damaged fuel (Baker and Welsh 2001). The sample jar label was difficult to read and the jar contents were completely dried. However, the sample readily re-wetted and appeared well behaved after water reconstitution. This sample was re-jarred and agitated.

\section{KC Floor Comp}

The KC Floor Comp sample was prepared for TCLP testing in the proportion $40 \mathrm{vol} \%$ of sample KC-4 and 60 vol\% of sample KC-5 (settled sludge basis; Silvers et al. 2000). Sample KC-4 was a consolidated sample taken from between barrels of open-bottom canisters containing highly damaged fuel from all three KE Basin bays and KC-5 was a consolidated sample taken from deep sludge areas on the main KE Basin floor from all three bays (Baker and Welsh 2001).

The compositions of the individual KC-4 and $\mathrm{KC}-5$ portions were combined to determine the composition of the KC Floor Comp sample reported in Table 8.3. The analyses reported in Baker and Welsh (2001) for this composite (dubbed KC-Flr Comp) were not used because the iron concentration was unrealistically high and no radionuclide concentrations were reported. The calculated uranium concentration is $10.3 \mathrm{wt} \%$ (dry basis). The sample was re-jarred and agitated.

\section{KE Container Comp and KE Container Comp Floc}

The KE Container Comp sample was prepared as composite of 8.5 vol\% KC-2/3, 28.9 vol\% KC-4, 34.1 vol\% KC-5 P250, and 28.5 vol\% FE-5 sludge (all settled-sludge basis). This sludge composite was created to emulate the composition of the KE floor, pit, and canister sludge that was containerized in the KW Basin. A portion of this composite was flocculated. The dry-basis composition, given in Table 8.4, was calculated based on the compositions of the constituent sludges (Delegard et al. 2007a) and applies to both the flocculated and non-flocculated portions. Due to the very small volumes, and the fact the sample jars were less than a year old, neither of these samples was agitated in the present testing. On a dry basis, the sludge contains $15.7 \mathrm{wt} \%$ uranium.

\section{KE NLOP}

The KE NLOP samples were taken from the K East Basin North Loadout Pit through a top-to-bottom isolation tube in four stratified sub-samples that were individually and collectively analyzed (Mellinger et al. 2004; additional analytical results in Shelor et al. 2004). Three jars, KE NLOP Jar \#1, Jar \#2, and Jar \#3, were prepared from the composite of the top-to-bottom samples. Sample KE NLOP Jar \#1 was mixed by a spatula instead of with the overhead drink mixer used to agitate many of the other samples. 
Sample KE NLOP Jar \#3 was not agitated but a small portion of the top layer was taken for analysis. The KE NLOP sludge contains only $2.51 \mathrm{wt} \%$ uranium (dry basis).

KE Pit

The KE Pit sample is a composite of $51.97 \mathrm{~g}$ (dry weight basis) of KES-P-16, $12.37 \mathrm{~g}$ of KES-Q-17, $111.14 \mathrm{~g}$ of KES-R-18, $54.43 \mathrm{~g}$ of KES-S-19, and 52.16 g of KES-T-20. All five constituent sludges were taken from the KE Weasel Pit. The composite was prepared for nitric acid dissolution/leach process testing (Carlson et al. 1998) and subsequently was used as a component of "KE Areas Sludge Composite" in further bench-scale leach testing (Schmidt et al. 1999).

Analyses are based on those of all contributing sludges except KES-T-20, for which only the acid-insoluble residue analysis was reported (Makenas et al. 1996). The silicon concentrations in each of the sludges were estimated for purposes of the present report based on the concentrations of acid-insoluble residue in each of the constituent sludges and the assumption that the residue was quartz, $\mathrm{SiO}_{2}$. The concentration of uranium in KES-T-20 was estimated to be $30.4 \mathrm{wt} \%$ (dry basis) based on its ${ }^{239,240} \mathrm{Pu}$ concentration and the ratio of uranium to ${ }^{239,240} \mathrm{Pu}$ found in the other KE Pit constituent sludges. The uranium concentration in the KE Pit composite is calculated to be $7.99 \mathrm{wt} \%$ (dry basis). This sample was re-jarred and agitated. 


\subsection{Sample $\mathrm{pH}$}

The $\mathrm{pH}$ values of the sludge samples that were agitated, plus the KE NLOP Jar \#1 and Jar \#3 samples, were determined using a calibrated $\mathrm{pH}$ probe. ${ }^{(1)}$ The $\mathrm{pH}$ meter was calibrated with commercial buffers ${ }^{(2)}$ at $\mathrm{pH} 4.01$ and 7.00, the measurements made for the supernatant waters from the sludges (or from DI water slurries of sludge if insufficient water was present), and the $\mathrm{pH}$ values of the buffers, including also a $\mathrm{pH} 10.01$ buffer, re-checked during and after the sludge measurements. The $\mathrm{pH}$ values of the standards matched the stated values within $0.07 \mathrm{pH}$ units in all cases for the $\mathrm{pH} 4.01$ and 7.00 buffers and within $0.15 \mathrm{pH}$ units for the $\mathrm{pH} 10.01$ buffer. The $\mathrm{pH}$ results are presented in Table 8.5 and compared there with $\mathrm{pH}$ values, where available, measured in prior testing.

As noted in Table 8.5, the KE NLOP Jar \#1 and Jar \#3 samples were measured 23 days later than the other samples. By use of the $\mathrm{pH}$ buffers, the $\mathrm{pH}$ probe was found to be still functional but had drifted from calibration. Therefore, the $\mathrm{pH}$ values measured for the KE NLOP sludge samples were adjusted to account for the drift registered by the buffers.

It was found that where prior data are available, the $\mathrm{pH}$ values in the present tests matched the prior values within $1 \mathrm{pH}$ unit except for the composite sample, KC-4 Whole. The $\mathrm{pH}$ of KC-4 Whole is 3.47 (an average of three measurements; 3.37, 3.52, and 3.51); the sister sample $\mathrm{KC}-4-2 \mathrm{pH}$ is 7.66, near the previously measured value of 7.8, and in line with the trend of decreasing $\mathrm{pH}$ with increasing uranium concentration observed for most other sludges (Figure 6.1). The reason for the unusually low $\mathrm{pH}$ of $\mathrm{KC}-4$ Whole is not known.

Another exception to the general trend of decreasing $\mathrm{pH}$ with increasing uranium concentration is found for the canister sludge sample 96-01. As noted previously, the analytical data for 96-01, including the data for uranium concentration, are suspect. Therefore, the relatively low $\mathrm{pH}$ measured for sample 96-01 may be an artifact of an understatement of the uranium concentration. The dry-basis values for uranium concentration reported for 96-01 (Makenas et al. 1997) were $<0.0257 \mathrm{wt} \%$ (by ICP), $0.0944 \mathrm{wt} \%$ (by phosphorescence), 82.4 and $85.4 \mathrm{wt} \%$ (by laser fluorimetry), and $65.0 \mathrm{wt} \%$ (by ICP with mass spectrometric detection). If one of the higher uranium concentration values were used, the $\mathrm{pH}$ vs. uranium concentration trend observed for most of the other sludges would hold for 96-01.

(1) Stick-type $\mathrm{pH}$ probe and temperature meter, Piccolo model HI 9214, Hanna Instruments, Woonsocket, RI.

(2) Buffers at $\mathrm{pH} 4.01$ and 10.01 from VWR Scientific, West Chester, PA; pH 7.00 buffer from Ricca Chemical, Arlington, TX. 


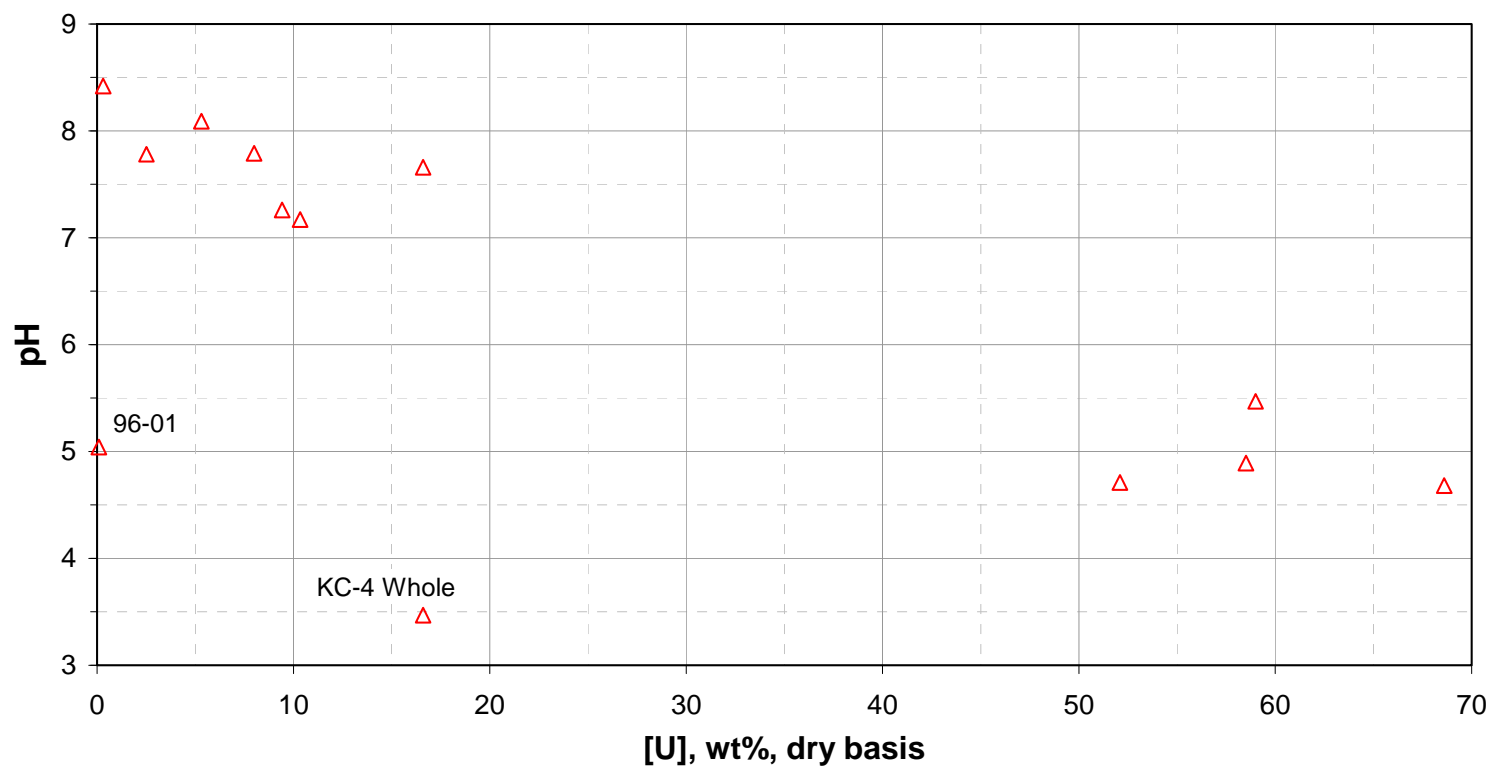

Figure 6.1. Sludge $\mathrm{pH}$ as a Function of Dry-Basis Uranium Concentration 


\subsection{Sludge Bulk Properties}

The bulk physical properties of the agitated sludges were measured by weighing well-mixed representative samples into volume-calibrated centrifuge cones, adding DI water, allowing re-settling for several days, measuring the settled sludge volume and total volume (with supernatant water), measuring the weights with supernatant water, and then decanting the water and drying the settled sludge to constant weight in an oven set to $105^{\circ} \mathrm{C}$. The settled densities of entire sludge samples also were determined by measuring the volumes and net sludge weights for those sludges packaged in new jars in the present tests. The new sample jars were volume-calibrated, before use in the hot cell, by adding 50 -ml increments of water to the tare-weighed jars and marking the jar walls at each level. The densities for samples and whole sludge jar items, Table 8.5 , match within $\sim 8 \%$ or better except for sample KC-1 M500, which differed by $23 \%$. Because of the difficulty of obtaining representative sludge samples, the jar values, where available, likely are more reliable than those obtained by the centrifuge cone method.

The settled density is shown generally to increase with increasing dry-basis uranium concentration in the sludge (Figure 7.1). The KE Pit and FE-5 samples deviate on the high side of this trend, having greater densities than their uranium concentrations would indicate. Both of these samples have relatively high iron concentrations (36.4 and $30.6 \mathrm{wt} \%$, respectively) which may have increased their densities. Because of its aberrant uranium concentration values, the point plotted for sample 96-01 is called out in Figure 7.1. In this case, its density is found to be in line with its (low) uranium concentration. If one of its high uranium concentration values were used in plotting, the 96-01 density would be out of line.

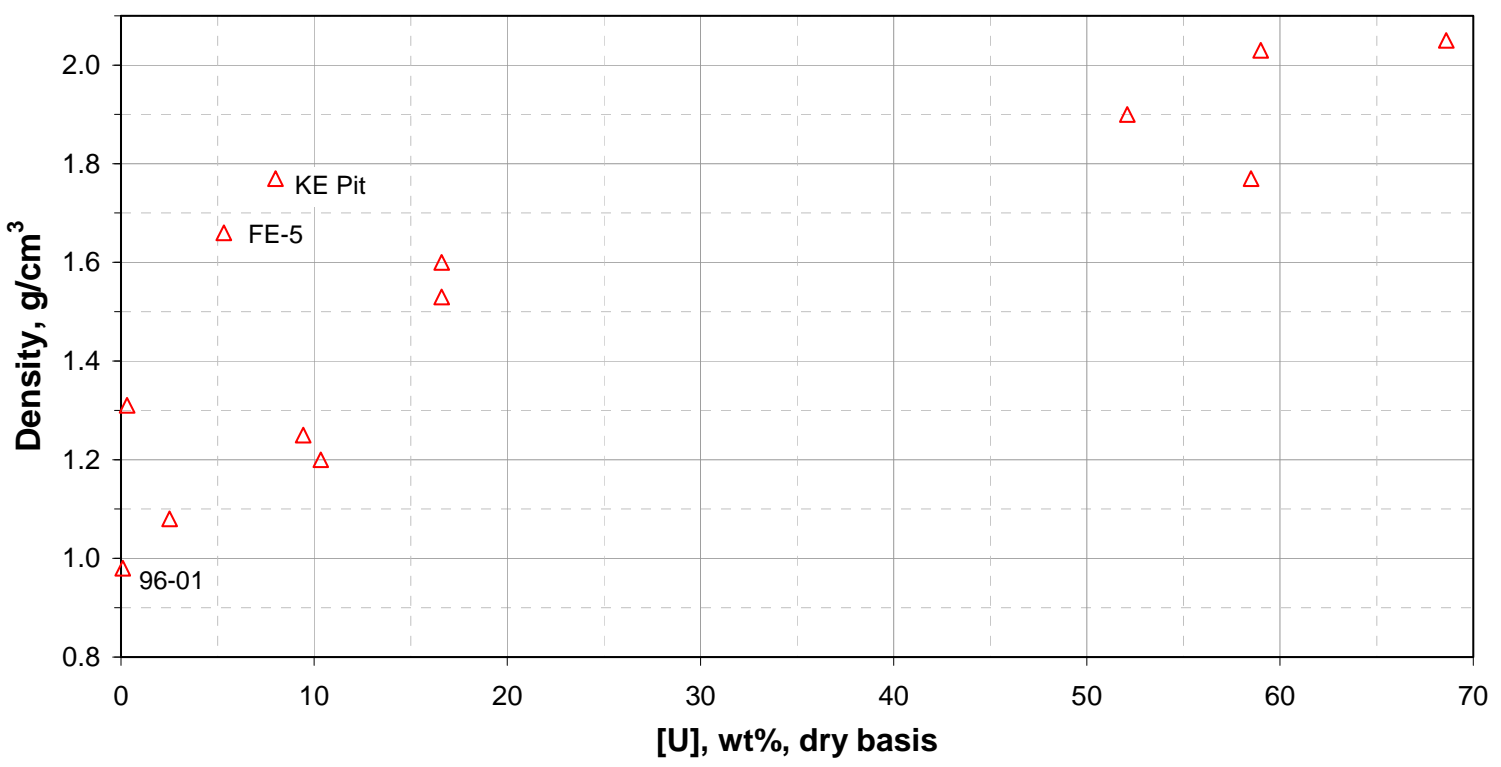

Figure 7.1. Sludge Density as a Function of Dry-Basis Uranium Concentration 



\subsection{X-Ray Diffraction Analysis Results}

A number of the sludges analyzed for density and $\mathrm{pH}$ also were analyzed by XRD. The samples included 96-13 KE Comp A, FE-5, KC-2/3 Comp, KC-4-2, KC-4 Whole, KC Floor Comp, and KE NLOP Jar \#1 (whole jar sub-sample) and Jar \#3 (upper layer sub-sample). One of the non-agitated single samples, 96-13 Solid Grad, also was analyzed by XRD. The XRD scans are presented in Appendix B and the sample results summarized in Table 8.6. For comparison, the phases identified in these sludges in prior characterization tests also are presented in Table 8.6. ${ }^{(1)}$ The prior results are based on analyses obtained during the original sludge characterization testing, if possible, or failing that, on analyses conducted during later testing.

As expected, the most prominent phases contained uranium for most samples. The only sample for which uranium was not in a prominent phase was the whole-jar sub-sample of KE NLOP Jar \#1. This material contains only $\sim 2.5 \mathrm{wt} \%$ uranium (dry basis) whereas the other samples contain from 4.1 to $79.8 \mathrm{wt} \%$ uranium (the uranium concentration in the upper layer sub-sample of KE NLOP Jar \#3 is not known).

The disappearance of chemically reduced uranium oxide phases (uraninites of the nominal formulas $\mathrm{UO}_{2}, \mathrm{U}_{4} \mathrm{O}_{9}$, and $\mathrm{U}_{3} \mathrm{O}_{7}$ ) in the recent samples is also noteworthy. Canister sludges, for which only uraninite phases were identified in past characterization (96-13 KE Comp A, 96-13 Solid Grad, and $\mathrm{KC}-2 / 3$ Whole), now contain no identifiable uraninite. Instead, only fully oxidized uranium(VI) phases (metaschoepite for all three samples, and a sodium uranium hydroxide hydrate for 96-13 KE Comp A) are found in the present analyses. No uraninite phase was found in any of the analyzed sludges.

Further mineralization of the uranium(VI) beyond metaschoepite is seen by the appearance of $\mathrm{Ca}\left(\mathrm{UO}_{2}\right)_{6} \mathrm{O}_{4}(\mathrm{OH})_{6}\left(\mathrm{H}_{2} \mathrm{O}\right)_{8}$, becquerelite, in the $\mathrm{KC}-4$ samples (which include $\mathrm{KC}-4$ Whole, $\mathrm{KC}-4-2$, and $\mathrm{KC}$ Floor Comp, which includes $\mathrm{KC}-4$ and $\mathrm{KC}-5$ sludge). A sodium uranyl oxide hydroxide hydrate also was found in the KC-4 Whole sample. No prior XRD analyses were performed for either KC-4 or KC-5 for comparison.

The FE-5 sample, which previously was found to contain quartz, $\mathrm{SiO}_{2}$, and two $\mathrm{FeO}(\mathrm{OH})$ phases, goethite and lepidocrocite, showed none of these phases in the recent sampling but did show a weak indication of the highly mineralized uranium phase uranophane, $\mathrm{Ca}\left(\mathrm{H}_{3} \mathrm{O}\right)_{2}\left(\mathrm{UO}_{2}\right)_{2}\left(\mathrm{SiO}_{4}\right)_{2}\left(\mathrm{H}_{2} \mathrm{O}\right)_{2}$, the first observation of this phase in $\mathrm{K}$ Basin sludge characterization. As noted in the Sludge Treatment Project hydrothermal testing report (Delegard et al. 2007a), uranophane is observed as a uranium alteration phase end member in uranium ore weathering and uranium oxide fuel oxidative degradation studies published in the technical literature.

The whole-jar sample of KE NLOP (taken from Jar \#1) contained a $\mathrm{SiO}_{2}$ phase and lesser indications of iron and chromium oxyhydroxides, $\mathrm{FeOOH}$ and $\mathrm{CrOOH}$. Only metaschoepite was found in the layer of sludge settled on the top of sample KE NLOP Jar \#3. Three years previously, only $\mathrm{SiO}_{2}$ and some unidentified peaks (which were verified to not be assignable to $\mathrm{FeOOH}$, metaschoepite, or other candidate phases) were found in the KE NLOP composite sample.

Together, the XRD analyses show that storage of sludge in the laboratory environment has resulted oxidation and continued mineral alteration of the uranium phases with the disappearance of the reduced uranium oxides of the form $\mathrm{UO}_{2 . x}$, where $\mathrm{x}=0-0.33$ (i.e., uraninite), to form fully oxidized hexavalent

(1) Jenson ED. 2007. Letter report, "XRD Examination of Samples," to CH Delegard, August 24, 2007, Pacific Northwest National Laboratory, Richland, WA. 
uranium $[\mathrm{U}(\mathrm{VI})]$ compounds starting with metaschoepite and proceeding to becquerelite (calcium uranium oxide hydroxide hydrate), sodium uranium oxide hydroxide, and uranophane (calcium uranium silicate oxide hydrate). 
Table 8.1. Sludge Archive Samples for Compositing, Re-Jarring, Blending, and Inventory

\begin{tabular}{|c|c|c|c|c|}
\hline Sludge Sample & $\begin{array}{c}\text { Sludge } \\
\text { Sub-sample } \\
\end{array}$ & Condition & \begin{tabular}{l|} 
Approx. \\
Vol., ml \\
\end{tabular} & $\begin{array}{c}\text { Blending } \\
\text { Time, s }\end{array}$ \\
\hline \multicolumn{5}{|c|}{ For compositing, re-jarring, and blending } \\
\hline \multirow{8}{*}{ KC-2/3 Comp } & $\begin{array}{l}\text { KC-2/3 Settling } \\
\text { Study }\end{array}$ & Mushy, thick mud, black, no hardpan, with water & 100 & \multirow{8}{*}{240} \\
\hline & KC-2/3 Whole & $\begin{array}{l}\text { Stiff saturated mud, green, with water, easily dispersed with } \\
\text { water }\end{array}$ & 70 & \\
\hline & KC-2/3 SS & Very stiff, glass broken to collect sample, with water & 100 & \\
\hline & KC-2 SSOL B & Very little solids with abundant water & 5 & \\
\hline & $\begin{array}{l}\mathrm{KC}-3+ \\
\mathrm{KC}-2 \text { Rec } 2\end{array}$ & Two jars with similar labels; solids wet but stuck to bottom & 40 & \\
\hline & KC-2/3 M250 & Hard chunks, very black, with water, easily dispersed with water & 40 & \\
\hline & KC-2/3 P250 & Can be scooped out & 25 & \\
\hline & $\mathrm{KC}-2 / 3 \mathrm{M} 250$ & $\begin{array}{l}\text { Very good with abundant water; source material for STP Tests } 1 \\
\text { and } 2\end{array}$ & $40-100$ & \\
\hline \multirow{5}{*}{ KC-4 Whole } & KC-4 & Abundant water & 50 & \multirow{5}{*}{120} \\
\hline & KC-4-L P6 & Sludge plug recovered, abundant water & $70-100$ & \\
\hline & KC-4 Dup LPG & Well settled solids, with water & $30-50$ & \\
\hline & KC-4 & Dry, but black, some retrieved as puck and some as powder & $30-40$ & \\
\hline & KC-4 Rec & Soft and readily suspendible & 40 & \\
\hline \multirow{2}{*}{$\mathrm{KC}-6$} & KC-6 & Fully saturated, beads are clumped but readily break up & 100 & \multirow{2}{*}{30} \\
\hline & KC-6 SSOL A & Some clumping but fully wet & 125 & \\
\hline \multirow{2}{*}{ KE Floc Comp } & $\begin{array}{l}\text { KE Floc Sludge } \\
\text { (floc'd.) }\end{array}$ & Saturated, original plug fell apart with shaking & 200 & \multirow{2}{*}{60} \\
\hline & $\begin{array}{l}\text { KE Floc Comp } \\
\text { (not floc'd.) }\end{array}$ & $\begin{array}{l}\text { Saturated, original plug fell apart with shaking but not as easily } \\
\text { as flocculated sludge }\end{array}$ & 70 & \\
\hline \multicolumn{5}{|c|}{ For re-jarring and blending only } \\
\hline KC-1 M500 & KC-1 M500 & Stiff but readily sluiced, suspended, and re-settled & $50-70$ & 20 \\
\hline FE-5 Comp 1 & FE-5 Comp 1 & Reddish brown, can be penetrated and scooped & 200 & 120 \\
\hline KC-4-2 & KC-4* & Dry chunks, water added and chunks broke up & 300 & 120 \\
\hline KC Floor Comp & KC Floor Comp & Wet, saturated, readily suspendible & $30-50$ & 0 \\
\hline KE Pit & KE Pit & Wet chunks, jar broken to recover & $150-200$ & 60 \\
\hline \multicolumn{5}{|c|}{ Transferred to HLRF and blended only } \\
\hline $96-01$ & $96-01$ & Very black solids & 15 & 30 \\
\hline $96-05$ & $96-05$ & Big chunks & 80 & 120 \\
\hline 96-13 KE Comp A & 96-13 KE Comp A & May contain some glass & 125 & 90 \\
\hline \multicolumn{5}{|c|}{ Re-jarred in SAL and currently staged in SAL } \\
\hline 96-08 SSOL & & Watered, dry before & 50 & NA \\
\hline 96-15 SSOL & & Watered, dry before & 100 & NA \\
\hline \multicolumn{5}{|c|}{ Transferred to HLRF and not re-jarred or blended } \\
\hline 96-09 SSOL & & None & 50 & NA \\
\hline 96-11 SSOL & & Very little sample & $<50$ & 0 \\
\hline 96-13 Settler Study & & Not watered, wet & 125 & NA \\
\hline 96-13 Solid Grad & & Solids not watered, not wet & 100 & NA \\
\hline 96-13 SSOL & & Not watered & 50 & NA \\
\hline KE NLOP Jar \#1 & & Good, with water & 165 & NA \\
\hline KE NLOP Jar \#2 & & Good, with water & 240 & NA \\
\hline KE NLOP Jar \#3 & & Good, with water & 240 & NA \\
\hline \multicolumn{5}{|c|}{ In HLRF and not re-jarred or blended } \\
\hline KC-6 carboy & & Good condition; 6-liter & 6400 & NA \\
\hline KE Container Com & & Moist, $70 \mathrm{ml}$ supernatant & 25 & NA \\
\hline KE Container Com & p Floc & Moist, $30 \mathrm{ml}$ supernatant & 10 & NA \\
\hline
\end{tabular}


Table 8.2. Source Information for Archived KE Basin Sludge Samples

\begin{tabular}{|c|c|c|c|c|c|}
\hline Sample ID & Source & $\begin{array}{l}\text { Sampling } \\
\text { Locations }\end{array}$ & \begin{tabular}{|c|} 
Barrel Type $\&$ \\
Material
\end{tabular} & $\begin{array}{c}\text { Sample } \\
\text { Date }\end{array}$ & Preparation and References \\
\hline $96-01$ & $\begin{array}{l}\text { Single closed-bottom canister } \\
\text { with good condition fuel }\end{array}$ & 1845 & Mark II, SS & 8 Apr 96 & Makenas et al. 1997 \\
\hline $96-05$ & $\begin{array}{l}\text { Single closed-bottom canister } \\
\text { with very poor condition fuel }\end{array}$ & 3128 & Mark II, SS & 9 Apr 96 & Makenas et al. 1997 \\
\hline 96-08 SSOL & $\begin{array}{l}\text { Single canister with poor } \\
\text { condition fuel }\end{array}$ & 2350 & Mark I, Al & $\begin{array}{c}10 \mathrm{Apr} \\
96\end{array}$ & Makenas et al. 1997 \\
\hline 96-11 SSOL & $\begin{array}{l}\text { Single empty closed-bottom } \\
\text { canister }\end{array}$ & 6073 & Mark I, SS & $\begin{array}{c}12 \mathrm{Apr} \\
96\end{array}$ & Makenas et al. 1997 \\
\hline $\begin{array}{c}96-13 \\
\text { (various) }\end{array}$ & $\begin{array}{l}\text { Single canister with poor } \\
\text { condition fuel (Settler Study, Solid } \\
\text { Grad, SSOL) }\end{array}$ & 5055 & Mark I, Al & $\begin{array}{c}18 \mathrm{Apr} \\
96\end{array}$ & Makenas et al. 1997 \\
\hline 96-15 SSOL & $\begin{array}{l}\text { Single canister with poor } \\
\text { condition fuel }\end{array}$ & 6070 & Mark I, Al & $\begin{array}{c}18 \mathrm{Apr} \\
96\end{array}$ & Makenas et al. 1997 \\
\hline FE-5 & $\begin{array}{l}\text { Weasel pit including South } \\
\text { Loadout Pit sludge }\end{array}$ & $\begin{array}{l}\text { One near south } \\
\text { wall } 8 \mathrm{ft} \text { from } \\
\text { east end; other } \\
\text { near center, } 11 \\
\mathrm{ft} \text { from west } \\
\text { end }\end{array}$ & 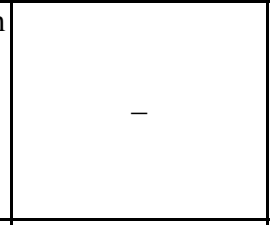 & \begin{tabular}{|l}
26 \\
Apr $\&$ \\
13 Jan 99
\end{tabular} \mid & $\begin{array}{l}\text { Composite created in 222-S Lab from KE-9 } \\
\text { and KE-10 single-pull samples; Baker \& } \\
\text { Welsh } 2001\end{array}$ \\
\hline KC-1 M500 & $\begin{array}{l}\text { Canister sludge from highly } \\
\text { damaged fuel collected from } \\
\text { one sampling location }\end{array}$ & $4569 \mathrm{E}$ & Mark $0, \mathrm{Al}$ & $\begin{array}{c}12 \text { Apr } \\
99\end{array}$ & $\begin{array}{l}\text { Sample passing } 500-\mu \mathrm{m} \text { sieve; } 88.7 \mathrm{wt} \% \text { of } \\
\text { total KC-1 wet solids; Baker \& Welsh } 2001 \text {; } \\
\text { Bredt et al. } 1999\end{array}$ \\
\hline $\mathrm{KC}-4$ & $\begin{array}{l}\text { Consol. smpl. fr. floor btwn. } \\
\text { barrels of open bot. can. w/ } \\
\text { highly dmgd. fuel fr. all } 3 \text { bays }\end{array}$ & $\begin{array}{l}0550 \\
4573 \\
5465\end{array}$ & $\begin{array}{l}\text { Mod. Co-Prod., Al } \\
\text { Mod. Co-Prod., Al } \\
\text { Mod. Co-Prod., Al } \\
\end{array}$ & $\begin{array}{c}30-31 \\
\text { Mar } 99\end{array}$ & Baker \& Welsh 2001; Bredt et al. 1999 \\
\hline KC-6 & $\begin{array}{l}\text { Consol. smpl. fr. floor area in } \\
\text { west bay known to be v. high in } \\
\text { ion exchange beads }\end{array}$ & 6758 & Mark $0, \mathrm{Al}$ & $\begin{array}{l}13 \& 26 \\
\text { Mar } 99\end{array}$ & Baker \& Welsh 2001; Bredt et al. 1999 \\
\hline KC Floor Comp & $\begin{array}{l}\text { Comp. of } 40 \text { vol\% KC-4 \& } 60 \\
\text { vol\% KC-5 (stl. sl. basis); KC-5 } \\
\text { consol. deep sl. fr. all } 3 \text { bays }\end{array}$ & $\begin{array}{l}\text { See above; } \\
\text { KC-5 4648, } \\
3133,0548\end{array}$ & Mod. Co-Prod., Al & $\begin{array}{c}29-31 \\
\text { Mar } 99\end{array}$ & Baker \& Welsh 2001; Silvers et al. 2000 \\
\hline $\begin{array}{l}\text { KE Container } \\
\text { Comp (\& Floc) }\end{array}$ & $\begin{array}{l}\text { Composite of KC-2/3, KC-4, } \\
\text { KC-5 P250 \& FE-5 }\end{array}$ & See above & See above & $\begin{array}{c}\text { See } \\
\text { above }\end{array}$ & Delegard et al. 2007a \\
\hline KE Floc Comp & $\begin{array}{l}\text { Composite of KC-4 M250, KC- } \\
\text { 5, FE-5, and KC Can Comp }\end{array}$ & See above & See above & $\begin{array}{c}\text { See } \\
\text { above }\end{array}$ & Baker \& Welsh 2001; Schmidt et al. 2004 \\
\hline KE NLOP & \multicolumn{3}{|c|}{$\begin{array}{l}\text { KE North Load Out Pit; top-to-bottom sample composite present in } \\
\text { three jars }(\# 1, \# 2 \text {, and \#3) }\end{array}$} & \begin{tabular}{|l|l|}
$13 \& 19$ \\
Dec 03 \\
\end{tabular} & Mellinger et al. 2004; Shelor et al. 2004 \\
\hline KE Pit & \multicolumn{3}{|c|}{ Weasel Pit composite of KES-P-16, -Q-17, -R-18, -S-19, \& -T-20 } & $\begin{array}{c}15-25 \\
\text { Sep } 95\end{array}$ & $\begin{array}{l}\text { Makenas et al. 1996; dry samples weighed \& } \\
\text { mixed w/ water, Carlson et al. } 1998\end{array}$ \\
\hline
\end{tabular}


Table 8.3. Chemical and Radiochemical Compositions of Archive Sludge Analyzed for Bulk Properties

\begin{tabular}{|c|c|c|c|c|c|c|c|c|c|c|c|c|}
\hline Sludge & $96-01^{(a)}$ & 96-05 & $\mid \begin{array}{l}96-13 \mathrm{KE} \\
\operatorname{Comp} \mathrm{A}^{(\mathrm{b})}\end{array}$ & FE-5 & $\begin{array}{c}\mathrm{KC}-1 \\
\mathrm{M500}^{(\mathrm{c})}\end{array}$ & $\mathrm{KC}-2 / 3$ & $\begin{array}{c}\text { KC-4 } \\
\text { Whole }\end{array}$ & $K C-6^{(d)}$ & $\begin{array}{c}\text { KC Floor } \\
\text { Comp }^{(e)}\end{array}$ & $\begin{array}{c}\text { KE Floc } \\
\text { Comp }^{(f)}\end{array}$ & $\begin{array}{c}\text { KE } \\
\text { NLOP }^{(\mathrm{g})}\end{array}$ & KE Pit ${ }^{(h)}$ \\
\hline \multicolumn{13}{|l|}{ Dry Basis } \\
\hline Element & \multicolumn{12}{|c|}{ Concentration, Wt $\%$} \\
\hline $\mathrm{Al}$ & 2.99 & 1.32 & 2.08 & 2.66 & 2.04 & 5.16 & 6.82 & 1.87 & 12.0 & 7.70 & 3.93 & 3.34 \\
\hline $\mathrm{Ca}$ & 0.0412 & 0.0779 & 0.0751 & 1.2 & 0.125 & 0.134 & 1.04 & 1.22 & 0.696 & 0.945 & 0.937 & 1.21 \\
\hline $\mathrm{Fe}$ & 0.0459 & 0.698 & 0.880 & 30.6 & 0.339 & 1.84 & 24.3 & 1.51 & 19.3 & 24.2 & 6.83 & 36.4 \\
\hline $\mathrm{Mg}$ & $\mathrm{BDL}^{(\mathrm{i})}$ & 0.221 & 0.194 & 0.146 & 0.0200 & 0.0462 & 0.33 & 0.225 & 0.236 & 0.230 & 0.122 & 0.194 \\
\hline $\mathrm{Na}$ & BDL & 0.0416 & 0.0395 & BDL & 0.237 & 0.24 & 0.36 & 3.26 & 0.368 & 0.365 & BDL & 0.0732 \\
\hline $\mathrm{Si}$ & $\mathrm{NR}^{(\mathrm{j})}$ & NR & NR & 0.330 & 0.160 & 0.752 & 4.91 & NR & 5.24 & 3.57 & 36.3 & 8.00 \\
\hline $\mathrm{U}^{(\mathrm{k})}$ & 0.0944 & 58.5 & 52.1 & 5.32 & 68.6 & 59.0 & 16.6 & 0.314 & 10.3 & 10.3 & 2.51 & 7.99 \\
\hline Compound $^{(1)}$ & 8.95 & 79.4 & 73.9 & 77.1 & 93.5 & 94.8 & 101.7 & 16.9 & 98.8 & 92.6 & 108.0 & 110.3 \\
\hline Radionuc. & \multicolumn{12}{|c|}{ Concentration, $\mu \mathrm{Ci} / \mathrm{g}$} \\
\hline${ }^{60} \mathrm{Co}$ & $\mathrm{BDL}$ & 0.892 & 1.27 & 0.875 & 0.209 & 0.441 & 1.08 & 0.185 & 1.09 & 1.02 & 0.280 & 1.59 \\
\hline${ }^{137} \mathrm{Cs}$ & 329 & 1140 & 748 & 170 & 392 & 860 & 1680 & 144 & 731 & 783 & 34.6 & 412 \\
\hline${ }^{154} \mathrm{Eu}$ & BDL & 18.6 & 11.3 & 0.985 & 8.62 & 8.14 & 2.6 & BDL & 1.69 & 1.68 & 0.542 & 2.41 \\
\hline${ }^{238} \mathrm{Pu}$ & 0.00541 & 16.2 & 36.6 & 2.06 & 21.5 & 16.2 & 4.91 & 0.0618 & 3.12 & 3.22 & 0.280 & 1.37 \\
\hline${ }^{239 / 240} \mathrm{Pu}$ & 0.0501 & 153 & 197 & 13.1 & 142 & 114 & 39.2 & 0.403 & 23.2 & 23.9 & 9.00 & 19.4 \\
\hline${ }^{241} \mathrm{Am}$ & BDL & 133 & 90.3 & 10.4 & 122 & 90.5 & 29.2 & 0.397 & 19.3 & 18.9 & 7.82 & 14.6 \\
\hline \multicolumn{13}{|c|}{ Settled Sludge Basis } \\
\hline El. / $\mathrm{H}_{2} \mathrm{O}$ & \multicolumn{12}{|c|}{ Concentration, $\mathrm{Wt}^{\mathrm{c}} \mathrm{o}^{(\mathrm{m})}$} \\
\hline $\mathrm{Al}$ & 1.66 & 0.706 & 1.22 & 1.56 & 1.38 & 3.04 & 3.83 & 0.802 & 5.72 & 2.53 & 0.562 & 2.03 \\
\hline $\mathrm{Ca}$ & 0.0229 & 0.0417 & 0.0439 & 0.704 & 0.0844 & 0.0791 & 0.584 & 0.523 & 0.331 & 0.310 & 0.134 & 0.737 \\
\hline $\mathrm{Fe}$ & 0.0255 & 0.373 & 0.515 & 18.0 & 0.229 & 1.09 & 13.7 & 0.648 & 9.17 & 7.92 & 0.977 & 22.1 \\
\hline $\mathrm{Mg}$ & BDL & 0.118 & 0.114 & 0.0857 & 0.0135 & 0.0273 & 0.185 & 0.0965 & 0.112 & 0.0755 & 0.0174 & 0.118 \\
\hline $\mathrm{Na}$ & BDL & 0.0223 & 0.0231 & BDL & 0.160 & 0.142 & 0.202 & 1.40 & 0.175 & 0.120 & BDL & 0.0445 \\
\hline $\mathrm{Si}$ & NR & NR & NR & 0.194 & 0.108 & 0.444 & 2.76 & NR & 2.50 & 1.17 & 5.19 & 4.86 \\
\hline $\mathrm{U}$ & 0.0524 & 31.3 & 30.5 & 3.12 & 46.3 & 34.8 & 9.33 & 0.135 & 4.92 & 3.37 & 0.359 & 4.85 \\
\hline $\mathrm{H}_{2} \mathrm{O}$ & 44.5 & 46.5 & 41.5 & 41.3 & 32.5 & 41.0 & 43.8 & 57.1 & 52.4 & 67.2 & 85.7 & 39.3 \\
\hline Radionuc. & \multicolumn{12}{|c|}{ Concentration, $\mu \mathrm{Ci} / \mathbf{g}^{(\mathrm{m})}$} \\
\hline${ }^{60} \mathrm{Co}$ & $\mathrm{BDL}$ & 0.477 & 0.743 & 0.514 & 0.141 & 0.260 & 0.607 & 0.0794 & 0.519 & 0.334 & 0.0400 & 0.962 \\
\hline${ }^{137} \mathrm{Cs}$ & 183 & 610 & 438 & 100 & 265 & 507 & 944 & 61.8 & 348 & 257 & 4.95 & 250 \\
\hline${ }^{154} \mathrm{Eu}$ & BDL & 9.95 & 6.59 & 0.578 & 5.82 & 4.80 & 1.46 & BDL & 0.802 & 0.552 & 0.0775 & 1.46 \\
\hline${ }^{238} \mathrm{Pu}$ & 0.00300 & 8.67 & 21.4 & 1.21 & 14.5 & 9.56 & 2.76 & 0.0265 & 1.49 & 1.06 & 0.0400 & 0.832 \\
\hline${ }^{239 / 240} \mathrm{Pu}$ & 0.0278 & 81.9 & 115 & 7.69 & 95.9 & 67.3 & 22.0 & 0.173 & 11.1 & 7.84 & 1.29 & 11.8 \\
\hline${ }^{241} \mathrm{Am}$ & $\mathrm{BDL}$ & 71.2 & 52.9 & 6.10 & 82.4 & 53.4 & 16.4 & 0.170 & 9.21 & 6.20 & 1.12 & 8.89 \\
\hline Reference $^{(\mathrm{n})}$ & 1 & 1 & 1,2 & 3 & 3,4 & 3 & 3 & $3,4,5$ & 3,7 & 3,6 & 8 & 5,9 \\
\hline
\end{tabular}


Table 8.3. Chemical and Radiochemical Compositions of Archive Sludge Analyzed for Bulk Properties (Cont'd)

Note that for sludge composites, the concentrations were weighted based on the contributions of only those individual components having reportable concentration values.

(a) The analytical data associated with sample 96-01 are of suspect quality but are reported for completeness. According to page 4 of Makenas et al. (1997), "Sample 96-01 had significantly higher reported $\mathrm{K}, \mathrm{Cr}, \mathrm{Ni}, \mathrm{Na}$, and $\mathrm{P}$ concentrations than the other samples" and "Sample 96-01 was again anomalous with a reported spread in uranium concentration from essentially 0 to $63 \mathrm{wt} \%$ of centrifuged sludge depending on the analysis method". Also, the plutonium and americium values are unusually low.

(b) Sample 96-13 KE Comp A is a composite of 61.92 $\mathrm{g}$ of 96-01, 62.92 $\mathrm{g}$ of 96-05, 74.05 g of 96-06 L, 57.37 g of 96-06 M/L, 39.03 g of 96-08, 124.54 g of 96-13, and 57.37 $\mathrm{g}$ of 96-15 (all dry basis). The composition was calculated from the compositions of the constituent sludges. For comparison, the dry basis composition of this composite, called "KE Canister Sludge Composite" in the report on validation testing of nitric acid treatment of sludge, is $1.84 \mathrm{wt} \% \mathrm{Al}, 0.118 \mathrm{wt} \% \mathrm{Ca}, 1.20 \mathrm{wt} \% \mathrm{Fe}, 0.118 \mathrm{wt} \% \mathrm{Si}$, $68.5 \mathrm{wt} \% \mathrm{U}, 809 \mu \mathrm{Ci}{ }^{137} \mathrm{Cs} / \mathrm{g}, 121 \mu \mathrm{Ci}{ }^{239,240} \mathrm{Pu} / \mathrm{g}$, and $95.3 \mu \mathrm{Ci}^{241} \mathrm{Am} / \mathrm{g}$ (Table 3.3 of Schmidt et al. 1999; other analytes not reported). The calculated total compound weight based on the Schmidt et al. (1999) values represents $95.3 \mathrm{wt} \%$ of the total mass (see footnote 1).

(c) $\mathrm{KC}-1 \mathrm{M} 500$ is $88.1 \mathrm{wt} \%$ of total $\mathrm{KC}-1$ wet solids; composition given for $\mathrm{KC}-1 \mathrm{M} 500$ is that of $\mathrm{KC}-1$.

(d) No analytical data are available for KC-6, which contains high concentrations of organic ion exchange resin beads. Data are from the similar sample KES-H-08. The acidinsoluble residue concentration is $9.73 \times 10^{5} \mu \mathrm{g} / \mathrm{g}$ (on a dry basis) for KES-H- 08 .

(e) KC Floor Comp is a composite that is $40 \mathrm{vol} \% \mathrm{KC}-4$ and $60 \mathrm{vol} \% \mathrm{KC}-5$ (settled basis). The composition was calculated from the compositions of the constituent sludges converted to a dry weight basis. The analyzed composition (Baker \& Welsh 2001) was not used because the iron concentration was unreasonable and no sodium or radchem values were reported.

(f) KE Floc Comp (flocculated KE Container Composite) is a composite of KC-4 M250 (50.6 wt\%), KC-5 (29.6 wt\%), FE-5 (19.4 wt\%), and KC Canister Composite (0.35 wt\%), all on a settled sludge basis. Composition calculated from the compositions of the constituent sludges (except KC Canister Composite) converted to a dry weight $\mathrm{Wt} \%)$,
basis.

(g) KE NLOP composition applies to all three KE NLOP jars (\#1, \#2, and \#3).

(h) KE Pit is a composite of $51.97 \mathrm{~g}$ of KES-P-16, $12.37 \mathrm{~g}$ of KES-Q-17, $111.14 \mathrm{~g}$ of KES-R-18, $54.43 \mathrm{~g}$ of KES-S-19, and $52.16 \mathrm{~g}$ of KES-T-20, all from the KE Weasel Pit All are dry sludge weights. Analyses are based on those of all contributing sludges except KES-T-20, for which only acid-insoluble residue analysis was reported. The silicon concentration was determined based on the concentrations of acid-insoluble residue in each of the constituent sludges and the assumption that the residue was $\mathrm{SiO}_{2}$. The uranium value for KES-T-20 $(30.4 \mathrm{wt} \%)$ was based on the ${ }^{239,240} \mathrm{Pu}$ value and the observed ratio of uranium-to- ${ }^{239,240} \mathrm{Pu}$ concentrations for the other KE Pit sludge contributors.

(i) BDL means below detection limit.

(j) NR means not reported.

(k) Uranium concentrations generally were those reported by phosphorescence, or by ICP if phosphorescence values were not available. KE NLOP values are based on laser fluorimetry.

(1) Based on assignment of the elements to the compounds $\mathrm{Al}(\mathrm{OH})_{3}, \mathrm{CaCO}_{3}, \mathrm{Fe}(\mathrm{OH})_{3}, \mathrm{MgCO}_{3}, \mathrm{Na}_{2} \mathrm{O}, \mathrm{SiO}_{2}$, and $\mathrm{UO}_{2.63} \cdot \mathrm{H}_{2} \mathrm{O}$. The compounds $\mathrm{Al}(\mathrm{OH})_{3}, \mathrm{CaCO}_{3}$, and $\mathrm{SiO} \mathrm{T}_{2}$ have been observed in genuine sludge. The compound $\mathrm{Fe}(\mathrm{OH})_{3}$ generally is X-ray indifferent but represents the likely state of the wet iron hydroxide solids present in sludge (though $\mathrm{Fe}_{2} \mathrm{O}_{3}$ and other crystalline iron compounds have been observed by XRD). The compound $\mathrm{MgCO}_{3}$ is assigned based on its chemical similarity to CaCO${ }_{3}$; $\mathrm{Mg}$ is too scarce to have a phase identifiable by XRD. The hypothetical compound $\mathrm{Na}_{2} \mathrm{O}$ represents the stoichiometry of sodium as oxide within more complex oxide minerals. The hypothetical compound $\mathrm{UO}_{2.63} \cdot \mathrm{H}_{2} \mathrm{O}$ represents a 50:50 (moles of $\mathrm{U}$ basis) mixture of $\mathrm{UO}_{2.25}$ and $\mathrm{UO}_{3} \cdot 2 \mathrm{H}_{2} \mathrm{O}$, the uranium phases most frequently observed in sludge (see Schmidt and Delegard 2003). The material balance shortfall for KC-6 (KES-H-08) is because of the presence of OIER, which is comprised largely of organic polymers, and mordenite (inorganic ion exchanger), both of which do not dissolve in the acid digestion done for this sample. All other sample analyses except KE Pit (acid digest) are based on fusion digests.

(m) Settled sludge analyses are calculated based on the water concentrations of the respective sludges. Note that drying and wetting in storage and during sample maintenance will alter these values and that water concentration values should be determined upon use to re-establish the component concentrations.

(n) References: 1 - Makenas et al. 1997; 2 - Schmidt et al. 1999; 3 - Baker and Welsh 2001; 4 - Bredt et al. 1999; 5 - Makenas et al. 1996; 6 - Silvers et al. 2000; 7 - Schmidt et al. 2004; 8 - Shelor et al. 2004; 9 - Carlson et al. 1998. 
Table 8.4. Chemical and Radiochemical Compositions for Archive Sludges That Were Not Re-Jarred

\begin{tabular}{|c|c|c|c|c|c|c|}
\hline Sludge & $\begin{array}{l}\text { 96-08 } \\
\text { SSOL }\end{array}$ & $\begin{array}{l}\text { 96-09 } \\
\text { SSOL }\end{array}$ & $\begin{array}{l}\text { 96-11 } \\
\text { SSOL }\end{array}$ & 96-13 & 96-15 & $\begin{array}{c}\text { KE } \\
\text { Cont. } \\
\text { Comp }\end{array}$ \\
\hline \multicolumn{7}{|l|}{ Dry Basis } \\
\hline Element & \multicolumn{6}{|c|}{ Concentration, Wt $\%$} \\
\hline $\mathrm{Al}$ & 7.86 & 13.9 & 6.66 & 1.45 & 1.60 & 7.82 \\
\hline $\mathrm{Ca}$ & 0.141 & 0.161 & 0.245 & 0.0698 & $\mathrm{BDL}^{(\mathrm{a})}$ & 0.770 \\
\hline $\mathrm{Fe}$ & 7.27 & 21.0 & 25.4 & 0.281 & 0.656 & 20.3 \\
\hline $\mathrm{Mg}$ & 0.168 & 0.198 & 0.0318 & 0.19 & 0.193 & 0.171 \\
\hline $\mathrm{Na}$ & 0.0728 & 0.0825 & 0.0595 & 0.043 & 0.0471 & 0.219 \\
\hline $\mathrm{Si}$ & $\mathrm{NR}^{(\mathrm{b})}$ & NR & NR & NR & NR & 2.81 \\
\hline $\mathrm{U}$ & 31.0 & 13.1 & 6.01 & 74.0 & 49.2 & 15.7 \\
\hline Compound $^{(\mathrm{c})}$ & 76.5 & 98.0 & 76.3 & 98.3 & 68.2 & 89.9 \\
\hline Radionuc. & \multicolumn{6}{|c|}{ Concentration, $\mu \mathrm{Ci} / \mathrm{g}$} \\
\hline${ }^{60} \mathrm{Co}$ & 0.694 & 2.44 & 1.98 & BDL & BDL & 0.912 \\
\hline${ }^{137} \mathrm{Cs}$ & 1180 & 276 & 223 & 648 & 795 & 521 \\
\hline${ }^{154} \mathrm{Eu}$ & 10.6 & 4.18 & 2.57 & 9.12 & 9.40 & 2.44 \\
\hline${ }^{238} \mathrm{Pu}$ & 17.4 & 5.89 & 3.59 & BDL & 8.20 & 4.78 \\
\hline${ }^{239 / 240} \mathrm{Pu}$ & 93.5 & 34.0 & 17.6 & 110 & 95.4 & 33.7 \\
\hline${ }^{241} \mathrm{Am}$ & 90.8 & 32.6 & 18.3 & 72.0 & 70.4 & 27.3 \\
\hline Reference $^{(\mathrm{d})}$ & 1 & 1 & 1 & 1 & 1 & 2 \\
\hline $\begin{array}{ll}\text { (a) } & \text { BDL me } \\
\text { (b) } & \text { NR mea } \\
\text { (c) } & \text { Based or } \\
& \mathrm{MgCO}_{3} \text {, } \\
& \text { have bee } \\
& \text { indiffere } \\
& \text { sludge ( } \\
& \mathrm{XRD}) . \\
& \mathrm{CaCO}_{3} ; \\
& \text { compour } \\
& \text { complex } \\
& 50: 50(\mathrm{~m} \\
& \text { most frec } \\
& \text { analyses } \\
\text { (d) } & \text { Referenc }\end{array}$ & $\begin{array}{l}\text { eans below } \\
\text { ns not repor } \\
n \text { assignmer } \\
\mathrm{Na}_{2} \mathrm{O}, \mathrm{SiO} \\
\text { en observed } \\
\text { ent but repre } \\
\text { though } \mathrm{Fe}_{2} \mathrm{C} \\
\mathrm{The} \text { compor } \\
\mathrm{Mg} \text { is too s} \\
\mathrm{nd} \mathrm{Na}_{2} \mathrm{O} \text { re } \\
\text { oxide mine } \\
\text { noles of } \mathrm{U} \mathrm{b} \\
\text { quently obs } \\
\text { based on fi } \\
\text { ces: } 1-\mathrm{Mal}\end{array}$ & $\begin{array}{l}\text { etection lim } \\
\text { ted. } \\
\text { t of the elem } \\
\text { and } \mathrm{UO}_{2.63} \\
\text { in genuine } \mathrm{s} \\
\text { ents the lik } \\
3 \text { and other } \\
\text { nd } \mathrm{MgCO}_{3} \\
\text { arce to have } \\
\text { resents the s } \\
\text { rals. The hy } \\
\text { asis) mixtur } \\
\text { rved in slud } \\
\text { sion digests } \\
\text { enas et al. } 1\end{array}$ & $\begin{array}{l}\text { ents to the } \mathrm{c} \\
\mathrm{H}_{2} \mathrm{O} \text {. The } \\
\text { udge. The } \\
\text { ly state of th } \\
\text { rystalline ir } \\
\text { assigned b } \\
\text { a phase ide } \\
\text { toichiometry } \\
\text { pothetical c } \\
\text { of } \mathrm{UO}_{2.25} \\
\text { ge (see Schn } \\
97 ; 2-\mathrm{Del}\end{array}$ & $\begin{array}{l}\text { mpounds A } \\
\text { ompounds } A \\
\text { ompound } \mathrm{F} \\
\text { e wet iron h } \\
\text { n compoun } \\
\text { sed on its cl } \\
\text { tifiable by } \mathrm{X} \\
\text { of sodium } \\
\text { mpound UC } \\
\text { d } \mathrm{UO}_{3} \cdot 2 \mathrm{H}_{2} \\
\text { idt and Del } \\
\text { gard et al. } 2\end{array}$ & $\begin{array}{l}(\mathrm{OH})_{3}, \mathrm{CaC} \\
1(\mathrm{OH})_{3}, \mathrm{CaC} \\
(\mathrm{OH})_{3} \text { gener } \\
\text { droxide sol } \\
\mathrm{s} \text { have been } \\
\text { emical simi } \\
\mathrm{RD} \text {. The hy } \\
5 \text { oxide with } \\
2.63 \cdot \mathrm{H}_{2} \mathrm{O} \text { rep } \\
\text {, the uraniu } \\
\text { gard 2003). } \\
007 \mathrm{a} \text {. }\end{array}$ & $\begin{array}{l}\mathrm{O}_{3}, \mathrm{Fe}(\mathrm{OH})_{3}, \\
\mathrm{O}_{3} \text {, and } \mathrm{SiO}_{2} \\
\text { ally is X-ray } \\
\text { ds present in } \\
\text { observed by } \\
\text { arity to } \\
\text { pothetical } \\
\text { n more } \\
\text { esents a } \\
\text { n phases } \\
\text { Sample }\end{array}$ \\
\hline
\end{tabular}


Table 8.5. Bulk Physical Properties and $\mathrm{pH}$ of Agitated Sludge

\begin{tabular}{|c|c|c|c|c|c|c|c|c|c|c|c|c|c|c|}
\hline Values & 96-01 & 96-05 & $\left|\begin{array}{c}96-13 \\
\text { KE } \\
\text { Comp A }\end{array}\right|$ & $\begin{array}{c}\text { FE-5 } \\
\text { Comp } \\
1\end{array}$ & $\begin{array}{l}\text { KC-1 } \\
\text { M500 }\end{array}$ & $\begin{array}{l}\mathrm{KC}-2 / 3 \\
\text { Comp }\end{array}$ & $\begin{array}{l}\text { KC-4 } \\
\text { Whole }\end{array}$ & KC-4-2 & KC-6 & $\begin{array}{c}\text { KE } \\
\text { Floc } \\
\text { Comp }\end{array}$ & $\begin{array}{c}\text { KC } \\
\text { Floor } \\
\text { Comp }\end{array}$ & $\begin{array}{c}\text { KE } \\
\text { NLOP } \\
\text { Jar } \\
\# 1^{(a)} \\
\end{array}$ & \begin{tabular}{|c|} 
KE \\
NLOP \\
Jar \\
\#3 $^{(\mathbf{a})}$ \\
\end{tabular} & KE Pit \\
\hline \multicolumn{15}{|c|}{ Starting Weight and Volume Values } \\
\hline Tube tare, $\mathrm{g}$ & 5.52 & 5.55 & 5.62 & 5.51 & 5.54 & 5.54 & 5.54 & 5.56 & 5.55 & 5.49 & 5.44 & 5.53 & 5.55 & 5.54 \\
\hline Tube + cap tare, $\mathrm{g}$ & 6.83 & 6.82 & 6.90 & 6.78 & 6.83 & 6.85 & 6.81 & 6.86 & 6.83 & 6.77 & 6.71 & 6.80 & 6.68 & 6.82 \\
\hline Gross sludge \& $\mathrm{H}_{2} \mathrm{O}, \mathrm{g}$ & 17.27 & 20.43 & 23.36 & 21.81 & 21.35 & 22.99 & 20.33 & 20.67 & 16.49 & 20.60 & 20.43 & 18.86 & 18.49 & 21.76 \\
\hline Settled sludge vol., ml & 0.25 & 2.30 & 5.60 & 5.45 & 2.45 & 5.10 & 4.70 & 4.05 & 2.00 & 6.50 & 1.10 & 9.90 & 3.80 & 3.95 \\
\hline Sludge \& $\mathrm{H}_{2} \mathrm{O}$ vol., $\mathrm{ml}$ & 10.45 & 11.85 & 11.40 & 11.45 & 11.95 & 10.90 & 10.70 & 11.65 & 9.05 & 12.20 & 13.50 & 11.45 & 11.45 & 11.90 \\
\hline Dry wt., g & 5.65 & 7.72 & 11.86 & 10.81 & 8.93 & 11.64 & 9.76 & 8.69 & 6.67 & 8.15 & 6.07 & 7.03 & 6.25 & 9.78 \\
\hline \multicolumn{15}{|c|}{ Net Weight and Volume Values } \\
\hline Settled sludge wt., g, in $\mathrm{H}_{2} \mathrm{O}$ & 0.25 & 4.06 & 10.66 & 9.03 & 5.02 & 10.34 & 7.52 & 6.21 & 2.61 & 8.13 & 1.32 & 10.51 & 4.16 & 6.99 \\
\hline Dry solid wt., g & 0.14 & 2.17 & 6.24 & 5.30 & 3.39 & 6.10 & 4.23 & 3.13 & 1.12 & 2.66 & 0.63 & 1.51 & 0.70 & 4.24 \\
\hline Dry solid vol., ml & 0.14 & 0.41 & 1.18 & 1.72 & 0.82 & 0.86 & 1.40 & 0.97 & 0.51 & 1.04 & 0.41 & 0.90 & 0.34 & 1.20 \\
\hline Total $\mathrm{H}_{2} \mathrm{O}$ wt., $\mathrm{g}$ & 10.31 & 11.44 & 10.22 & 9.73 & 11.13 & 10.04 & 9.30 & 10.68 & 8.54 & 11.16 & 13.09 & 10.55 & 11.11 & 10.70 \\
\hline $\mathrm{H}_{2} \mathrm{O}$ in settled sludge, $\mathrm{g}$ or $\mathrm{ml}$ & 0.11 & 1.89 & 4.35 & 3.73 & 1.63 & 4.24 & 3.30 & 3.08 & 1.49 & 5.46 & 0.69 & 9.00 & 3.46 & 2.75 \\
\hline \multicolumn{15}{|c|}{ Densities and Water/Solids Concentrations } \\
\hline Stl. sludge $\rho$, sample, $\mathrm{g} / \mathrm{cm}^{3}$ & 0.98 & 1.77 & 1.90 & 1.66 & 2.05 & 2.03 & 1.60 & 1.53 & 1.31 & 1.25 & 1.20 & 1.06 & 1.09 & 1.77 \\
\hline Sludge jar $\rho, \mathrm{g} / \mathrm{cm}^{3}$ & $\mathrm{NM}^{(\mathrm{b})}$ & NM & NM & 1.68 & 2.66 & 2.14 & 1.56 & 1.60 & 1.20 & 1.30 & 1.34 & NM & NM & 1.92 \\
\hline Solids in settled sludge, vol\% & 56.4 & 18.0 & 21.0 & 31.5 & 33.5 & 16.8 & 29.9 & 24.0 & 25.4 & 15.9 & 37.0 & 9.1 & 8.9 & 30.5 \\
\hline Solids in settled sludge, $\mathrm{wt} \%$ & 55.5 & 53.5 & 58.5 & 58.7 & 67.5 & 59.0 & 56.2 & 50.4 & 42.9 & 32.8 & 47.6 & 14.3 & 16.7 & 60.7 \\
\hline Solids particle $\rho, \mathrm{g} / \mathrm{cm}^{3}$ & 0.96 & 5.26 & 5.30 & 3.08 & 4.13 & 7.10 & 3.01 & 3.23 & 2.21 & 2.57 & 1.55 & 1.67 & 2.05 & 3.52 \\
\hline $\mathrm{H}_{2} \mathrm{O}$ in settled sludge, vol\% & 43.6 & 82.0 & 79.0 & 68.5 & 66.5 & 83.2 & 70.1 & 76.0 & 74.6 & 84.1 & 63.0 & 90.9 & 91.1 & 69.5 \\
\hline $\mathrm{H}_{2} \mathrm{O}$ in settled sludge, $\mathrm{wt} \%$ & 44.5 & 46.5 & 41.5 & 41.3 & 32.5 & 41.0 & 43.8 & 49.6 & 57.1 & 67.2 & 52.4 & 85.7 & 83.3 & 39.3 \\
\hline \multicolumn{15}{|l|}{ pH } \\
\hline $\mathrm{pH}$ & 5.04 & 4.89 & $\begin{array}{c}4.71 \\
\text { (avg. 2) }\end{array}$ & 8.09 & 4.68 & 5.47 & $\begin{array}{c}3.47 \\
\text { (avg. 3) }\end{array}$ & 7.66 & $\begin{array}{c}8.42 \\
\text { (avg. 2) }\end{array}$ & $\begin{array}{c}7.26 \\
\text { (avg. 2) }\end{array}$ & 7.17 & $7.82^{(\mathrm{c})}$ & $7.75^{(\mathrm{c})}$ & 7.79 \\
\hline Prior $\mathrm{pH}$ values & 6.06 & $4.4-6.8$ & NM & 7.9 & 5.1 & $5.0-5.4$ & & .8 & 7.4 & NM & NM & & 31 & NM \\
\hline Reference $^{(\mathrm{d})}$ & 1 & 1 & $\begin{array}{c}- \\
\end{array}$ & 2 & 2 & 3 & & 3 & 2 & $\begin{array}{l}- \\
\end{array}$ & - & & 3 & - \\
\hline \multicolumn{15}{|l|}{ Sludge Quantities } \\
\hline Volume settled sludge, $\mathrm{ml}$ & 15 & 80 & 125 & 260 & 20 & 425 & 120 & 165 & 140 & 260 & 25 & $165^{(\mathrm{e})}$ & 240 & 125 \\
\hline \multicolumn{15}{|c|}{$\begin{array}{l}\text { (a) KE NLOP Jar \#1 from whole-jar mixed sample; KE NLOP Jar \#3 from sample of top layer. } \\
\text { (b) NM means not measured. }\end{array}$} \\
\hline $\begin{array}{l}\text { KE NLOP Jar \#1 and Jar \# } \\
\text { The pH meter response, ch } \\
\text { NLOP Jar \#1 and Jar \#3 w } \\
\text { (d) References: } 1 \text { - Makenas } \\
\text { (e) Sludge volume in KE NLC }\end{array}$ & $\begin{array}{l}\text { pH value } \\
\text { ecked usins } \\
\text { re adjustec } \\
\text { al. } 1997 ; \\
\text { P Jar \#2 is }\end{array}$ & $\begin{array}{l}\text { s meas'd. J } \\
\text { g pH } 7.00 \\
\text { upwards } \\
2-\text { Bryan } \\
240 \mathrm{ml} .\end{array}$ & $\begin{array}{l}\text { July } 19,200 \\
\text { and } 10.0 \text { sta } \\
0.41 \mathrm{pH} \text { un } \\
\text { et al. } 2004 \text {; }\end{array}$ & $\begin{array}{l}07 \text {; other s } \\
\text { andards, sl }\end{array}$ & $\begin{array}{l}\text { samples me } \\
\text { howed } 6.6 \\
\text { olated fron } \\
\text { zard et al. } 2\end{array}$ & $\begin{array}{l}\text { eas'd. } 23 \mathrm{~d} \\
4 \text { (avg. of } 6 \\
\mathrm{~m} \text { the low } \mathrm{n} \\
2000 ; 4-1\end{array}$ & $\begin{array}{l}\text { ays earlier } \\
6.62 \text { and } 6 \\
\text { neasured } p \\
\text { Mellinger }\end{array}$ & $\begin{array}{l}\text { on June } 2 \\
66) \text { and } 9 . \\
\text { oH bias for } \\
\text { et al. } 2004\end{array}$ & $\begin{array}{l}6,200 \\
43 \text {, res } \\
\text { and for }\end{array}$ & $\begin{array}{l}\text { media } \\
\text { ively. }\end{array}$ & $\begin{array}{l}y \text { after } \\
\text { erefor }\end{array}$ & $\begin{array}{l}\text { ling th } \\
\text { le } \mathrm{pH} v\end{array}$ & brate & $\begin{array}{l}\text { meter. } \\
\text { or KE }\end{array}$ \\
\hline
\end{tabular}


Table 8.6. Summary of XRD Findings for Archived Sludge Samples

\begin{tabular}{|c|c|c|c|c|c|c|c|c|c|c|c|}
\hline \multirow[b]{2}{*}{ Phase } & \multirow[b]{2}{*}{ Formula } & \multirow[b]{2}{*}{ PDF \# } & \multicolumn{9}{|c|}{ Prominence in Sludge ${ }^{(a)}$} \\
\hline & & & 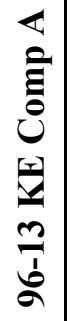 & 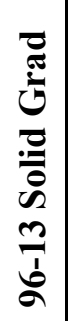 & $\begin{array}{l}n \\
n \\
c \\
c\end{array}$ & 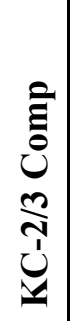 & $\underset{v}{\mathfrak{y}}$ & 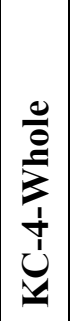 & 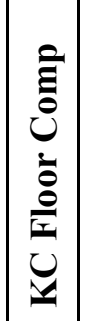 & 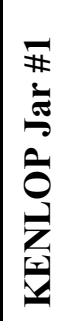 & 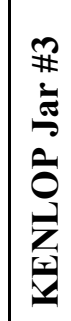 \\
\hline \multicolumn{12}{|l|}{ Present Testing } \\
\hline \multirow{2}{*}{ Metaschoepite } & $\left(\mathrm{UO}_{2}\right)_{4} \mathrm{O}(\mathrm{OH})_{6}\left(\mathrm{H}_{2} \mathrm{O}\right)_{5}$ & $70-4765$ & $\mathrm{H}$ & $\mathrm{H}$ & & $\mathrm{H}$ & $\mathrm{M}$ & & & & $\mathrm{M}$ \\
\hline & $\mathrm{UO}_{3} \cdot 2 \mathrm{H}_{2} \mathrm{O}$ & $43-3634$ & & & & & & & & & $\mathrm{H}$ \\
\hline \multirow{2}{*}{ Schoepite ${ }^{(b)}$} & $\mathrm{UO}_{3} \cdot 2 \mathrm{H}_{2} \mathrm{O}$ & $13-241$ & $\mathrm{H}$ & $\mathrm{M}$ & & $\mathrm{H}$ & & $\mathrm{M}$ & & & $\mathrm{M}$ \\
\hline & $\left(\left(\mathrm{UO}_{2}\right)_{8} \mathrm{O}_{2}(\mathrm{OH})_{12}\right)\left(\mathrm{H}_{2} \mathrm{O}\right)_{12}$ & $86-1383$ & & & & & $?$ & & & & \\
\hline $\begin{array}{l}\text { Sodium uranium } \\
\text { hydroxide hydrate }\end{array}$ & $\mathrm{Na}_{2}\left(\mathrm{UO}_{2}\right)_{6}(\mathrm{OH})_{14} \cdot 4 \mathrm{H}_{2} \mathrm{O}$ & $36-117$ & $\mathrm{M}$ & & & & & & & & \\
\hline $\begin{array}{l}\text { Sodium uranyl oxide } \\
\text { hydroxide hydrate }\end{array}$ & $\mathrm{Na}_{2}\left(\mathrm{UO}_{2}\right)_{6} \mathrm{O}_{4}(\mathrm{OH})_{6} \cdot 8 \mathrm{H}_{2} \mathrm{O}$ & $53-876$ & & & & & & $\mathrm{M}$ & & & \\
\hline \multirow{2}{*}{ Becquerelite } & $\mathrm{Ca}\left(\mathrm{UO}_{2}\right)_{6} \mathrm{O}_{4}(\mathrm{OH})_{6}\left(\mathrm{H}_{2} \mathrm{O}\right)_{8}$ & $84-1505$ & & & & & $\mathrm{H}$ & & $\mathrm{H}$ & & \\
\hline & $\mathrm{Ca}\left(\mathrm{UO}_{2}\right)_{6} \mathrm{O}_{4}(\mathrm{OH})_{6}\left(\mathrm{H}_{2} \mathrm{O}\right)_{8}$ & $84-513$ & & & & & & $\mathrm{H}$ & & & \\
\hline Uranophane & $\begin{array}{c}\mathrm{Ca}\left(\mathrm{H}_{3} \mathrm{O}\right)_{2}\left(\mathrm{UO}_{2}\right)_{2}\left(\mathrm{SiO}_{4}\right)_{2}\left(\mathrm{H}_{2} \mathrm{O}\right. \\
)_{2}\end{array}$ & $83-1847$ & & & $\mathrm{~L}$ & & & & & & \\
\hline \multirow{2}{*}{ Quartz } & $\mathrm{SiO}_{2}$ & $82-511$ & & & & & & & $\mathrm{M}$ & & \\
\hline & $\mathrm{SiO}_{2}$ & $65-466$ & & & & & & & & $?$ & \\
\hline Cristobalite & $\mathrm{SiO}_{2}$ & $89-3606$ & & & & & & & & $\mathrm{M}$ & \\
\hline Bayerite & $\mathrm{Al}(\mathrm{OH})_{3}$ & 74-119 & & & & & & & $\mathrm{L}$ & & \\
\hline Iron oxide hydroxide & $\mathrm{FeOOH}$ & $73-2326$ & & & & & & & & $\mathrm{~L}$ & \\
\hline Guyanaite & $\mathrm{CrOOH}$ & $70-1115$ & & & & & & & & $\mathrm{~L}$ & \\
\hline Nichromite & $\mathrm{NiCr}_{2} \mathrm{O}_{4}$ & $85-935$ & & & & & & & $?$ & & \\
\hline \multicolumn{12}{|l|}{ Prior Testing } \\
\hline Uraninite & $\mathrm{UO}_{2}, \mathrm{U}_{4} \mathrm{O}_{9}, \mathrm{U}_{3} \mathrm{O}_{7}$ & & $\mathrm{X}$ & $\mathrm{X}$ & & $\mathrm{X}$ & \multirow{5}{*}{\multicolumn{2}{|c|}{ NM }} & \multirow{5}{*}{$\mathrm{NM}$} & & \\
\hline Metaschoepite & $\mathrm{UO}_{3} \cdot 2 \mathrm{H}_{2} \mathrm{O}$ & & $\mathrm{X}$ & & & $\mathrm{X}$ & & & & & \\
\hline Quartz & $\mathrm{SiO}_{2}$ & & & & $\mathrm{X}$ & & & & & & $X$ \\
\hline $\begin{array}{l}\text { Gibbsite, bayerite, } \\
\text { nordstrandite }\end{array}$ & $\mathrm{Al}(\mathrm{OH})_{3}$ & & & & & $X$ & & & & & \\
\hline $\begin{array}{l}\text { Goethite, } \\
\text { lepidocrocite }\end{array}$ & $\mathrm{FeO}(\mathrm{OH})$ & & & & $X$ & & & & & & \\
\hline \multicolumn{3}{|l|}{ References $^{(\mathrm{c})}$} & 1 & 1 & 2 & 3 & - & - & - & & 4 \\
\hline \multicolumn{12}{|c|}{$\begin{array}{l}\text { (a) Prominence: } \mathrm{H}=\text { high; } \mathrm{M}=\text { medium; } \mathrm{L}=\text { low; ? = questionable; } \mathrm{X}=\text { present; } \mathrm{NM}=\text { not measured. } \\
\left.\text { (b) The schoepite phase } \mathrm{UO}_{3} \cdot 2 \mathrm{H}_{2} \mathrm{O} \text { has the formula of metaschoepite. The phase }\left(\mathrm{UO}_{2}\right)_{8} \mathrm{O}_{2}(\mathrm{OH})_{12}\right)\left(\mathrm{H}_{2} \mathrm{O}\right)_{12} \text { is equivalent to } \\
\mathrm{UO}_{3} \cdot 2.25 \mathrm{H}_{2} \mathrm{O} \text { and is a true schoepite. } \\
\text { (c) References: } 1 \text { - Makenas et al. 1997; } 2 \text { - Baker and Welsh 2001; } 3 \text { - Delegard et al. 2000; } 4 \text { - Melllinger et al. } 2004 .\end{array}$} \\
\hline
\end{tabular}





\subsection{Conclusions}

Samples of sludge were collected from the K East fuel storage basin (KE Basin) floor, contiguous pits (Weasel Pit, North Load Out Pit, Dummy Elevator Pit, and Tech View Pit), and fuel storage canisters between 1995 and 2003 for chemical and radionuclide concentration analysis, physical property determination, and chemical process testing work. Because of the value of the sludge in this testing and because of the cost of obtaining additional fresh samples, an ongoing program of sludge preservation has taken place with the goals to track the sludge identities and preserve, as well as possible, the sludge composition by keeping the sludge in sealed jars and maintaining water coverage on the sludge.

In the present work, like samples of KE Basin sludge were consolidated into new containers, other sludges put into new containers, and other sludge samples from the SAL and from storage in the RPL basement were gathered into the HLRF to maintain better sample tracking. The quantities of the various sludge samples were measured. The physical properties (bulk and particle density and water and solids concentrations), the $\mathrm{pH}$, and the solid phases present in a number of these samples were determined and are reported. The results are compared with results, where available, found in prior testing.

Results of the compositing and characterization are summarized in Table 9.1 and show sludge sources, volumes, uranium concentrations, and densities. It was found that settled sludge densities generally increase with increasing uranium concentration while sludge $\mathrm{pH}$ generally decreases with increasing uranium concentration. The X-ray diffraction results (not shown in Table 9.1), where available, show disappearance of uranium(IV) phases (various uraninites, $\mathrm{UO}_{2}, \mathrm{U}_{4} \mathrm{O}_{9}$, and $\mathrm{U}_{3} \mathrm{O}_{7}$ ) observed during prior characterization testing and the appearance of uranium(VI) compounds including metaschoepite, becquerelite, and uranophane. 
Table 9.1. Sources and Properties of Archived KE Basin Sludge Samples

\begin{tabular}{|c|c|c|c|c|c|c|c|}
\hline \multirow[t]{2}{*}{ Sample ID } & \multirow[t]{2}{*}{ Source } & \multirow{2}{*}{$\begin{array}{c}\text { Sample } \\
\text { Date }\end{array}$} & \multirow{2}{*}{$\begin{array}{l}\text { Stld. } \\
\text { Vol., } \\
\text { ml }\end{array}$} & \multirow{2}{*}{\begin{tabular}{|c|}
$\mathbf{U}]$ \\
$\mathbf{d r y}$ \\
$\mathbf{w t} \%$
\end{tabular}} & \multicolumn{2}{|c|}{ 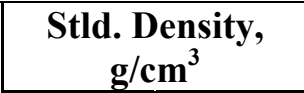 } & \multirow[t]{2}{*}{ References } \\
\hline & & & & & Present & Original & \\
\hline $96-01$ & $\begin{array}{l}\text { Single closed-bottom canister with } \\
\text { good condition fuel }\end{array}$ & 8 Apr 96 & 15 & 0.0944 & 0.98 (cone) & $\begin{array}{c}2.09 \\
(1997)\end{array}$ & Makenas et al. 1997 \\
\hline $96-05$ & $\begin{array}{l}\text { Single closed-bottom canister with } \\
\text { very poor condition fuel }\end{array}$ & 9 Apr 96 & 80 & 58.5 & 1.77 (cone) & $\begin{array}{c}2.34 \\
(1997)\end{array}$ & Makenas et al. 1997 \\
\hline 96-08 SSOL & $\begin{array}{l}\text { Single canister with poor condition } \\
\text { fuel }\end{array}$ & $\begin{array}{c}10 \mathrm{Apr} \\
96\end{array}$ & 50 & 31.0 & - & $\begin{array}{c}1.19 \\
(1997)\end{array}$ & Makenas et al. 1997 \\
\hline 96-09 SSOL & Single empty open-bottom canister & $\begin{array}{c}11 \mathrm{Apr} \\
96\end{array}$ & 50 & 13.1 & - & $\begin{array}{c}1.07 \\
(1997) \\
\end{array}$ & Makenas et al. 1997 \\
\hline 96-11 SSOL & Single empty closed-bottom canister & $\begin{array}{l}12 \text { Apr } \\
96\end{array}$ & $<50$ & 6.01 & - & $\begin{array}{l}1.23 \\
\text { (calc., } \\
1997)\end{array}$ & Makenas et al. 1997 \\
\hline $\begin{array}{c}96-13 \\
\text { (various) }\end{array}$ & $\begin{array}{l}\text { Single canister with poor condition } \\
\text { fuel (Settler Study, Solid Grad, } \\
\text { SSOL) }\end{array}$ & $\begin{array}{l}18 \text { Apr } \\
96\end{array}$ & $\begin{array}{c}125,100 \\
50\end{array}$ & 74.0 & - & $\begin{array}{l}2.458 \\
(1997)\end{array}$ & Makenas et al. 1997 \\
\hline \begin{tabular}{||c|}
$96-13$ \\
KE Comp A
\end{tabular} & \begin{tabular}{|l|} 
Composite of samples $96-01,-05,-06$ \\
$-08,-13$, and -15 from single canisters \\
with good to very poor condition fuel
\end{tabular} & $\begin{array}{c}8-18 \mathrm{Apr} \\
96\end{array}$ & 125 & 52.1 & 1.90 (cone) & - & $\begin{array}{l}\text { Makenas et al. } 1997 ; \\
\text { Table } 3.2 \text { of Schmidt et } \\
\text { al. } 1999\end{array}$ \\
\hline 96-15 SSOL & $\begin{array}{l}\text { Single canister with poor condition } \\
\text { fuel }\end{array}$ & $\begin{array}{c}18 \mathrm{Apr} \\
96\end{array}$ & 100 & 49.2 & - & $\begin{array}{c}1.845 \\
(1997) \\
\end{array}$ & Makenas et al. 1997 \\
\hline FE-5 & $\begin{array}{l}\text { Weasel pit including South Loadout } \\
\text { Pit sludge }\end{array}$ & $\begin{array}{l}26 \text { Apr } \& \\
13 \text { Jan } 99\end{array}$ & 260 & 5.32 & $\begin{array}{c}1.66(\text { cone }) \\
1.68 \text { (jar) }\end{array} \mid$ & 1.50 & $\begin{array}{l}\text { Composite created in } \\
\text { 222-S Lab from KE-9 and } \\
\text { KE-10 single-pull } \\
\text { samples; Baker \& Welsh } \\
2001\end{array}$ \\
\hline KC-1 M500 & $\begin{array}{l}\text { Canister sludge from highly damaged } \\
\text { fuel collected from one sampling } \\
\text { location }\end{array}$ & $\begin{array}{l}12 \text { Apr } \\
99\end{array}$ & 20 & 68.6 & $\left|\begin{array}{c}2.05 \text { (cone) } \\
2.66 \text { (jar) }\end{array}\right|$ & 1.5 & $\begin{array}{l}\text { Sample passing } 500-\mu \mathrm{m} \\
\text { sieve; } 88.7 \text { wt } \% \text { of total } \\
\text { KC-1 wet solids; Baker \& } \\
\text { Welsh } 2001 \text {; Bredt et al. } \\
\text { 1999; Bryan et al. } 2004\end{array}$ \\
\hline$K C-2 / 3$ & $\begin{array}{l}\text { KC-2; consol. smpl. fr. fuel stor. can. } \\
\text { barrels w/ hi. dmgd. fuel fr. all } 3 \text { bays }\end{array}$ & $\begin{array}{c}4-13 \text { Mar } \\
99\end{array}$ & 425 & 500 & 2.03 (cone) & 2.13 & $\begin{array}{l}\text { Composite } \mathrm{KC}-2 / 3 \\
\text { created in } 325 \mathrm{Lab} ; \text { Baker }\end{array}$ \\
\hline $\mathrm{N} C-2 / 3$ & $\begin{array}{l}\text { KC-3; consol. smpl. fr. can. barrels } \\
\text { with mod. dmgd. fuel fr. all } 3 \text { bays }\end{array}$ & $\begin{array}{c}1-8 \text { Apr } \\
99\end{array}$ & $4 \angle 5$ & 39.0 & 2.14 (jar) & (1999) & $\begin{array}{l}\text { \& Welsh 2001; Bredt et } \\
\text { al. } 1999\end{array}$ \\
\hline KC-4 Whole & $\begin{array}{l}\text { Consol. smpl. fr. floor btwn. barrels of } \\
\text { fopen bot. can. w/ highly dmod. fuel fr. }\end{array}$ & $30-31$ & 120 & 16.6 & $\begin{array}{c}1.60 \text { (cone) } \\
1.56 \text { (jar) } \\
\end{array}$ & 1.235 & Baker \& Welsh 2001; \\
\hline $\mathrm{KC}-4-2$ & $\begin{array}{l}\text { open bot. can. W/ nigniy amga. ruer ir. } \\
\text { all } 3 \text { bays }\end{array}$ & Mar 99 & 165 & 10.0 & $\begin{array}{l}1.53 \text { (cone) } \\
1.60 \text { (jar) } \\
\end{array}$ & 1.253 & \\
\hline KC-6 & $\begin{array}{l}\text { Consol. smpl. fr. floor area in west } \\
\text { bay known to be v. high in ion }\end{array}$ & $13 \& 26$ & 140 & 0.314 & $\begin{array}{c}1.31 \text { (cone) } \\
1.20 \text { (jar) } \\
\end{array}$ & 1.1 & $\begin{array}{l}\text { Baker \& Welsh 2001; } \\
\text { Bredt et al. 1999; Bryan }\end{array}$ \\
\hline \begin{tabular}{||l|} 
KC-6 carboy \\
\end{tabular} & exchange beads & & 6400 & & - & & et al. 2004 \\
\hline $\begin{array}{l}\text { KC Floor } \\
\text { Comp }\end{array}$ & $\begin{array}{l}\text { Comp. of } 40 \text { vol\% KC-4 \& } 60 \text { vol\% } \\
\text { KC-5 (stl. sl.); KC-5 consol. deep sl. } \\
\text { fr. all } 3 \text { bays (smpl. } 29 \text { Mar 99) }\end{array}$ & $\begin{array}{c}29-31 \\
\text { Mar } 99\end{array}$ & 25 & 10.3 & $\begin{array}{c}1.20(\text { cone }) \\
1.34 \text { (jar) }\end{array} \mid$ & $\begin{array}{l}1.21 \\
(\text { calc., } \\
2000) \\
\end{array}$ & $\begin{array}{l}\text { Baker \& Welsh 2001; } \\
\text { Silvers et al. } 2000\end{array}$ \\
\hline \begin{tabular}{|} 
KE Container \\
Comp \& \\
Floc $^{(a)}$
\end{tabular} & $\begin{array}{l}\text { Composite of } \mathrm{KC}-2 / 3, \mathrm{KC}-4, \mathrm{KC}-5 \\
\mathrm{P} 250 \text { \& FE-5 }\end{array}$ & $\begin{array}{l}13 \mathrm{Jan}- \\
26 \mathrm{Apr} \\
99\end{array}$ & 25,10 & 15.7 & - & \begin{tabular}{|l|}
$1.65,1.53$ \\
(cone) \\
$1.54,1.45$ \\
(jar) \\
\end{tabular} & Delegard et al. 2007a \\
\hline $\begin{array}{l}\text { KE Floc } \\
\text { Comp }\end{array}$ & $\begin{array}{l}\text { Composite of KC-4 M250, KC-5, FE- } \\
\text { 5, and KC Can Comp }\end{array}$ & $\begin{array}{c}13 \mathrm{Jan}- \\
26 \mathrm{Apr} \\
99\end{array}$ & 260 & 10.3 & $\begin{array}{c}1.25 \text { (cone) } \\
1.30 \text { (jar) }\end{array} \mid$ & $\begin{array}{l}1.25 \\
(2004)\end{array}$ & $\begin{array}{l}\text { Baker \& Welsh 2001; } \\
\text { Schmidt et al. } 2004\end{array}$ \\
\hline KE NLOP & $\begin{array}{l}\text { KE North Load Out Pit; top-to-bottom } \\
\text { sample composite present in three jars } \\
(\# 1, \# 2 \text {, and } \# 3)\end{array}$ & $\begin{array}{l}13 \& 19 \\
\text { Dec } 03\end{array}$ & 645 & 2.51 & 1.06 (cone) & $\begin{array}{l}1.23 \\
(2004)\end{array}$ & $\begin{array}{l}\text { Mellinger et al. 2004; } \\
\text { Shelor et al. } 2004\end{array}$ \\
\hline KE Pit & $\begin{array}{l}\text { Weasel Pit composite of KES-P-16, - } \\
\text { Q-17, -R-18, -S-19, \& -T-20 }\end{array}$ & $\begin{array}{l}15-25 \\
\text { Sep } 95\end{array}$ & 125 & 7.99 & $\begin{array}{c}1.77 \text { (cone) } \\
1.92 \text { (jar) }\end{array}$ & - & $\begin{array}{l}\text { Makenas et al. 1996; dry } \\
\text { smpls. weigh \& mix w/ } \\
\mathrm{H}_{2} \mathrm{O} \text {, Carlson et al. } 1998\end{array}$ \\
\hline
\end{tabular}




\subsection{References}

Baker RB and TL Welsh. 2001. "Laboratory Data from the Consolidated and Single Pull Core Sludge Sampling Campaigns,” Internal FH Memo, 01-SNF/RBB-004, May 10, 2001, Spent Nuclear Fuel Project, Fluor Hanford, Richland, WA.

Bredt PR, CH Delegard, AJ Schmidt, and KL Silvers. 1999. Testing and Analysis of Consolidated Sludge Samples from the 105 K East Basin Floor and Canisters. PNNL-13341, Pacific Northwest National Laboratory, Richland, WA.

Bryan SA, CH Delegard, AJ Schmidt, RL Sell, and KL Silvers, SR Gano, and BM Thornton. 2004. Gas Generation from K East Basin Sludges - Series II Testing. PNNL-13446, Rev. 1, Pacific Northwest National Laboratory, Richland, WA.

Carlson CD, CH Delegard, IE Burgeson, AJ Schmidt, KL Silvers. 1998. K Basin Sludge Conditioning Testing: Nitric Acid Dissolution Testing of K East Area Sludge Composite, Small- and Large-Scale Testing. PNNL-12109, Pacific Northwest National Laboratory, Richland, WA.

Delegard CH, SA Bryan, AJ Schmidt, PR Bredt, CM King, RL Sell, LL Burger, and KL Silvers. 2000. Gas Generation from K East Basin Sludges - Series I Testing. PNNL-13320, Pacific Northwest National Laboratory, Richland, WA.

Delegard CH, AP Poloski, AJ Schmidt, and JW Chenault. 2005. Characterization of Compaction and Dryout Properties of KE Basin Sludge During Long-Term Storage. PNNL-15092, Pacific Northwest National Laboratory, Richland, WA.

Delegard CH, AJ Schmidt, and BM Thornton. 2007a. Hydrothermal Testing of K Basin Sludge and N Reactor Fuel at Sludge Treatment Project Operating Conditions. PNNL-16496, Pacific Northwest National Laboratory, Richland, WA.

Delegard CH, AJ Schmidt, and AP Poloski. 2007b. Test Plan: Sludge Treatment Project Corrosion Process Chemistry Follow-on Testing, PNNL-16776, Pacific Northwest National Laboratory, Richland, WA.

Elmore MR, AJ Schmidt, KL Silvers, BM Thornton, and SR Gano. 2000. Chemical and Radiochemical Analysis of Consolidated Sludge Samples from the K East Basin. PNNL-13360, Pacific Northwest National Laboratory, Richland, WA.

Makenas BJ, TL Welsh, RB Baker, DR Hansen, and GR Golcar. 1996. Analysis of Sludge from Hanford K East Basin Floor and Weasel Pit. WHC-SP-1182, Rev. 0, Westinghouse Hanford Company, Richland, WA.

Makenas BJ, TL Welsh, RB Baker, EW Hoppe, AJ Schmidt, J Abrefah, JM Tingey, PR Bredt, and GR Golcar. 1997. Analysis of Sludge from Hanford K East Basin Canisters. HNF-SP-1201, DE\&S Hanford, Inc., Richland, WA.

Mellinger GB, CH Delegard, AJ Schmidt, and GJ Sevigny. 2004. Evaluation and Recommendation of Waste Form and Packaging for Disposition of the K East Basin North Loadout Pit Sludge. PNNL-14741, Pacific Northwest National Laboratory, Richland, WA. 
Poloski AP, PR Bredt, AJ Schmidt, RG Swoboda, JW Chenault, and SR Gano. 2002. Thermal Conductivity and Shear Strength of K Basin Sludge. PNNL-13911, Pacific Northwest National Laboratory, Richland, WA.

Schmidt AJ and CH Delegard. 2003. Updated Volumetric Expansion Factors for K Basin Sludge During Storage. PNNL-14228, Pacific Northwest National Laboratory, Richland, WA.

Schmidt AJ, CH Delegard, KL Silvers, PR Bredt, CD Carlson, EW Hoppe, JC Hayes, DE Rinehart, SR Gano, and BM Thornton. 1999. Validation Testing of the Nitric Acid Dissolution Step Within the K Basin Sludge Pretreatment Process. PNNL-12120, Pacific Northwest National Laboratory, Richland, WA.

Schmidt AJ, RT Hallen, DS Muzatko, and SR Gano. 2004. KE Basin Sludge Flocculant Testing. PNNL-14730, Pacific Northwest National Laboratory, Richland, WA.

Shelor JL, M Epstein, MG Plys, JP Sloughter, J Abrefah, CH Delegard, and AJ Schmidt. 2004. Gas Behavior in Large Diameter Containers (LDCs) During and Following Loading with 105K East North Loadout Pit Sludge. SNF-22059, Fluor Hanford, Richland, WA.

Silvers KL, JJ Wagner, and RT Steele. 2000. TCLP Preparation and Analysis of K East Basin Composite Sludge Samples. PNNL-13280, Pacific Northwest National Laboratory, Richland, WA.

Steen FH. 2000. KE Basin Floor \& Pit Composite Sludge Samples \& Analytical Results for the Final Report. HNF-6053, Fluor Hanford, Richland, WA. 


\section{Appendix A}

\section{Sludge Sample Uses for Characterization and Process}

Testing 

Table A.1. Use of Sludge Samples for Property and Process Testing

\begin{tabular}{|c|c|c|c|c|c|}
\hline Activity & Samples Used & \multicolumn{3}{|c|}{ Composites Generated } & Reference \\
\hline $\begin{array}{l}\text { Uranium and radionuclide } \\
\text { leaching from KE Pit sludges }\end{array}$ & $\begin{array}{l}\text { KES-P-16, -Q-17, -R-18, -S- } \\
19, \text { and -T-20 }\end{array}$ & \multicolumn{3}{|c|}{$\begin{array}{l}\text { KE Weasel Pit: } 51.97 \mathrm{~g} \text { of P-16, } 12.37 \mathrm{~g} \text { of Q-17, } 111.14 \mathrm{~g} \text { of R-18, } 54.43 \mathrm{~g} \text { of } \\
\mathrm{S}-19 \text {, and } 52.16 \mathrm{~g} \text { of T-20 (dry basis) }\end{array}$} & $\begin{array}{l}\text { Carlson et al. } \\
1998\end{array}$ \\
\hline $\begin{array}{l}\text { Validation testing of nitric acid } \\
\text { treatment of sludge }\end{array}$ & $\begin{array}{l}\text { 96-01, 96-05, 96-06 L, 96-06 } \\
\text { M/L, 96-08, 96-13, 96-15; } \\
\text { KES-A-02, -B-03, -C-04, -F- } \\
\text { 10, -G-07, -I-15, -K-12, -L-01, } \\
\text {-N-05, -E-11, -J-06, -D-14, -P- } \\
\text { 16, -Q-17, -R-18, -S-19, and - } \\
\text { T-20; KES-H-08 }\end{array}$ & $\begin{array}{l}\text { KE Canister Sludge: } 61.92 \\
\mathrm{~g} \text { of } 96-01,62.92 \mathrm{~g} \text { of } 96- \\
05,74.05 \mathrm{~g} \text { of } 96-06 \mathrm{~L}, \\
57.37 \mathrm{~g} \text { of } 96-06 \mathrm{M} / \mathrm{L}, \\
39.03 \mathrm{~g} \text { of } 96-08,124.54 \mathrm{~g} \\
\text { of } 96-13 \text {, and } 57.37 \mathrm{~g} \text { of } \\
96-15 \text { (dry basis) } \\
\end{array}$ & \multicolumn{2}{|c|}{$\begin{array}{l}\text { KE Area Sludge: } 0.39 \mathrm{~g} \text { of A- } 02,1.41 \mathrm{~g} \text { of B- } 03, \\
0.39 \mathrm{~g} \text { of C- } 04,10.54 \mathrm{~g} \text { of F-10,1.25 g of G- } 07, \\
1.60 \mathrm{~g} \text { of } \mathrm{I}-15,1.65 \mathrm{~g} \text { of } \mathrm{K}-12,0.36 \mathrm{~g} \text { of L- }-1,6.48 \\
\mathrm{~g} \text { of } \mathrm{N}-05,17.67 \mathrm{~g} \text { of E-11, 30.31 g of J-06, } 7.75 \mathrm{~g} \\
\text { of K-14, } 18.93 \mathrm{~g} \text { of P-16, } 4.51 \mathrm{~g} \text { of Q-17, } 40.49 \mathrm{~g} \\
\text { of R-18,19.83 g of S-19, and } 19.00 \mathrm{~g} \text { of T-20 (dry } \\
\text { basis) }\end{array}$} & $\begin{array}{l}\text { Schmidt et al. } \\
1999\end{array}$ \\
\hline $\begin{array}{l}\text { Receipt, recovery, and physical } \\
\text { characterization (recovery, } \\
\text { settling, sieving, \% water, shear } \\
\text { strength, and acid calorimetry) }\end{array}$ & $\begin{array}{l}\mathrm{KC}-1, \mathrm{KC}-2 / 3, \mathrm{KC}-4, \mathrm{KC}-5 \text {, } \\
\text { and } \mathrm{KC}-6\end{array}$ & \multicolumn{3}{|l|}{ None } & Bredt et al. 1999 \\
\hline Chemical characterization & $\begin{array}{l}\mathrm{KC}-1, \mathrm{KC}-2 / 3, \mathrm{KC}-4 \text {, and } \mathrm{KC}- \\
5\end{array}$ & \multicolumn{3}{|l|}{ None } & $\begin{array}{l}\text { Elmore et al. } \\
2000\end{array}$ \\
\hline TCLP testing and ICP & $\begin{array}{l}\mathrm{KC}-1, \mathrm{KC}-2 / 3, \mathrm{KC}-4 \text {, and } \mathrm{KC}- \\
5\end{array}$ & \multicolumn{3}{|c|}{$\begin{array}{l}\text { KC Can Comp: } 10.6 \text { wt } \% \text { KC-1 }+69.8 w t \% \\
\text { KC-2/3 }+19.6 \text { wt } \% \text { KC-2/3 P250 (settled) }\end{array}$} & $\begin{array}{l}\text { Silvers et al. } \\
2000\end{array}$ \\
\hline Shipped to 222-S for testing & $\mathrm{KC}-1, \mathrm{KC}-2 / 3$, and $\mathrm{KC}-4$ & \multicolumn{3}{|c|}{ Shipped as KC Can Comp and KC-4 } & Steen 2000 \\
\hline Gas Generation Series I & $\mathrm{KC}-2 / 3, \mathrm{KC}-4, \mathrm{KC}-5$ & \multicolumn{3}{|l|}{ None } & $\begin{array}{l}\text { Delegard et al. } \\
2000\end{array}$ \\
\hline Gas Generation Series II & $\begin{array}{l}\text { KC-1, KC-6, FE-1, FE-3, FE-5, } \\
\text { FE-6, and 96-06 }\end{array}$ & \multicolumn{3}{|l|}{ None } & Bryan et al. 2004 \\
\hline Gas Generation Series III & $\begin{array}{l}\mathrm{KC}-1, \mathrm{KC}-2 / 3, \mathrm{KC}-4, \text { and } \mathrm{KC}- \\
5\end{array}$ & \multicolumn{3}{|c|}{ KC Can Comp and KC Floor Comp used (see Silvers et al. 2000) } & $\begin{array}{l}\text { Schmidt et al. } \\
2003\end{array}$ \\
\hline $\begin{array}{l}\text { Thermal conductivity and shear } \\
\text { strength testing }\end{array}$ & $\begin{array}{l}\mathrm{KC}-1, \mathrm{KC}-2 / 3, \mathrm{KC}-4, \text { and } \mathrm{KC}- \\
5\end{array}$ & \multicolumn{3}{|c|}{ KC Can Comp and KC Floor Comp used (see Silvers et al. 2000) } & $\begin{array}{l}\text { Poloski et al. } \\
2002\end{array}$ \\
\hline Flocculation testing & $\begin{array}{l}\mathrm{KC}-4, \mathrm{KC}-5, \mathrm{FE}-5 \text {, and } \mathrm{KC} \\
\text { Can Comp }\end{array}$ & \multicolumn{3}{|c|}{$\begin{array}{l}\text { Flocculation composite (Floc Comp) and flocculated sludge is } 50.6 \mathrm{wt} \% \mathrm{KC}-4 \\
\text { M250, 29.6 wt } \% \text { KC-5, } 19.4 \mathrm{wt} \% \text { FE-5, and } 0.35 \mathrm{wt} \% \mathrm{KC} \text { Can Comp (see } \\
\text { PNNL-13280) }\end{array}$} & $\begin{array}{l}\text { Schmidt et al. } \\
2004\end{array}$ \\
\hline $\begin{array}{l}\text { Gas generation testing of sludge } \\
\text { and grouted and absorbent forms }\end{array}$ & KE NLOP & \multicolumn{3}{|c|}{ Composite of top-to-bottom collection from isolation tube sampling } & $\begin{array}{l}\text { Mellinger et al. } \\
2004\end{array}$ \\
\hline Long-term compaction studies & $\begin{array}{l}\mathrm{FE}-5, \mathrm{KC}-1, \mathrm{KC}-2 / 3, \mathrm{KC}-4, \\
\mathrm{KC}-5,96-13 \text {, and } \mathrm{KE} \text { NLOP }\end{array}$ & \multicolumn{3}{|c|}{$\begin{array}{l}\text { SNF Comp came from residues of gas generation tests "SNF + Can 60L" and } \\
\text { "SNF + Floor 60L", reported in PNNL-14346, using } 64 \text { vol } \% \text { KC Floor Comp } \\
+36 \text { vol\% KC Can Comp plus crushed \& part-corroded fuel }\end{array}$} & $\begin{array}{l}\text { Delegard et al. } \\
2005\end{array}$ \\
\hline $\begin{array}{l}\text { Sludge Treatment Process } \\
\text { testing }\end{array}$ & $\mathrm{KC}-2 / 3, \mathrm{KC}-4, \mathrm{KC}-5$, and FE-5 & \multicolumn{3}{|c|}{$\begin{array}{l}\mathrm{KE} \text { Container Comp }=\mathrm{KE} \text { Floc Container Comp }=12.5 \mathrm{wt} \% \mathrm{KC}-2 / 3,25.3 \mathrm{wt} \% \\
\mathrm{KC}-4,32.2 \mathrm{wt} \% \mathrm{KC}-5 \mathrm{P} 250 \text {, and } 30.0 \mathrm{wt} \% \mathrm{FE}-5 \text {. Also used KC-2/3 M250. }\end{array}$} & $\begin{array}{l}\text { Delegard et al. } \\
2007 \mathrm{a}\end{array}$ \\
\hline
\end{tabular}



Appendix B

XRD Scans 



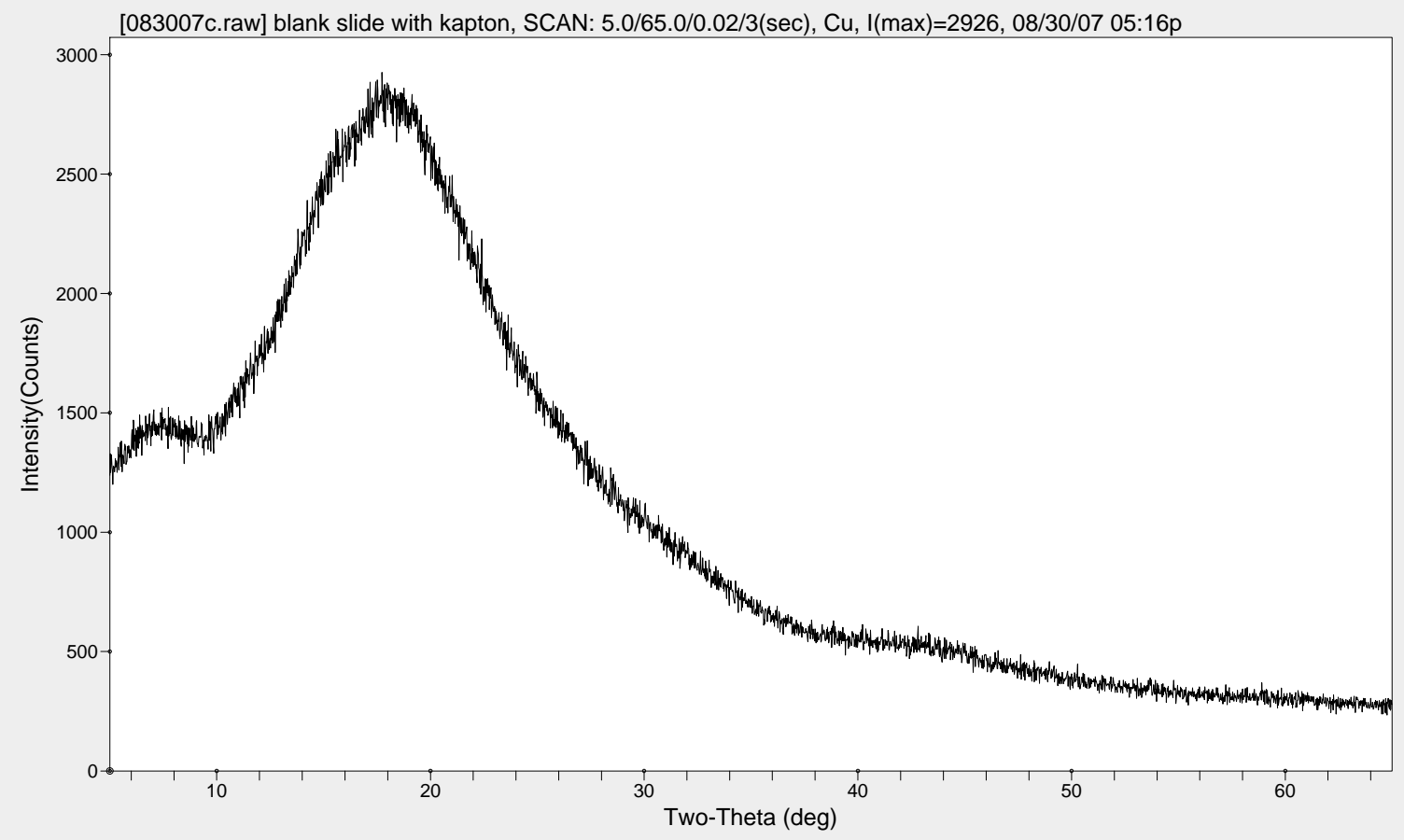

Figure B.1. Raw X-Ray Diffraction Scan for a Blank Slide 

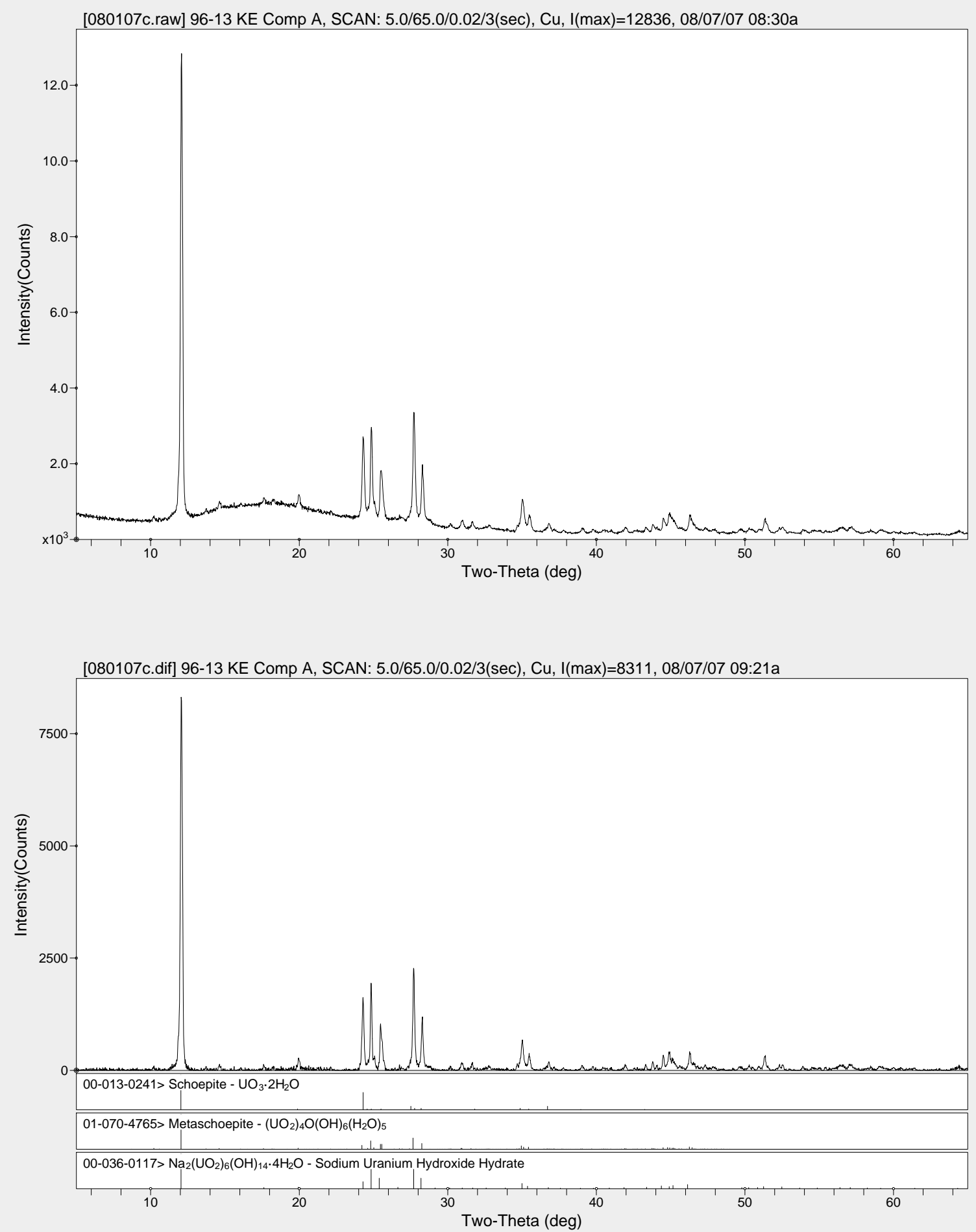

Figure B.2. Raw and Background-Corrected X-Ray Diffraction Scan for 96-13 KE Comp A 

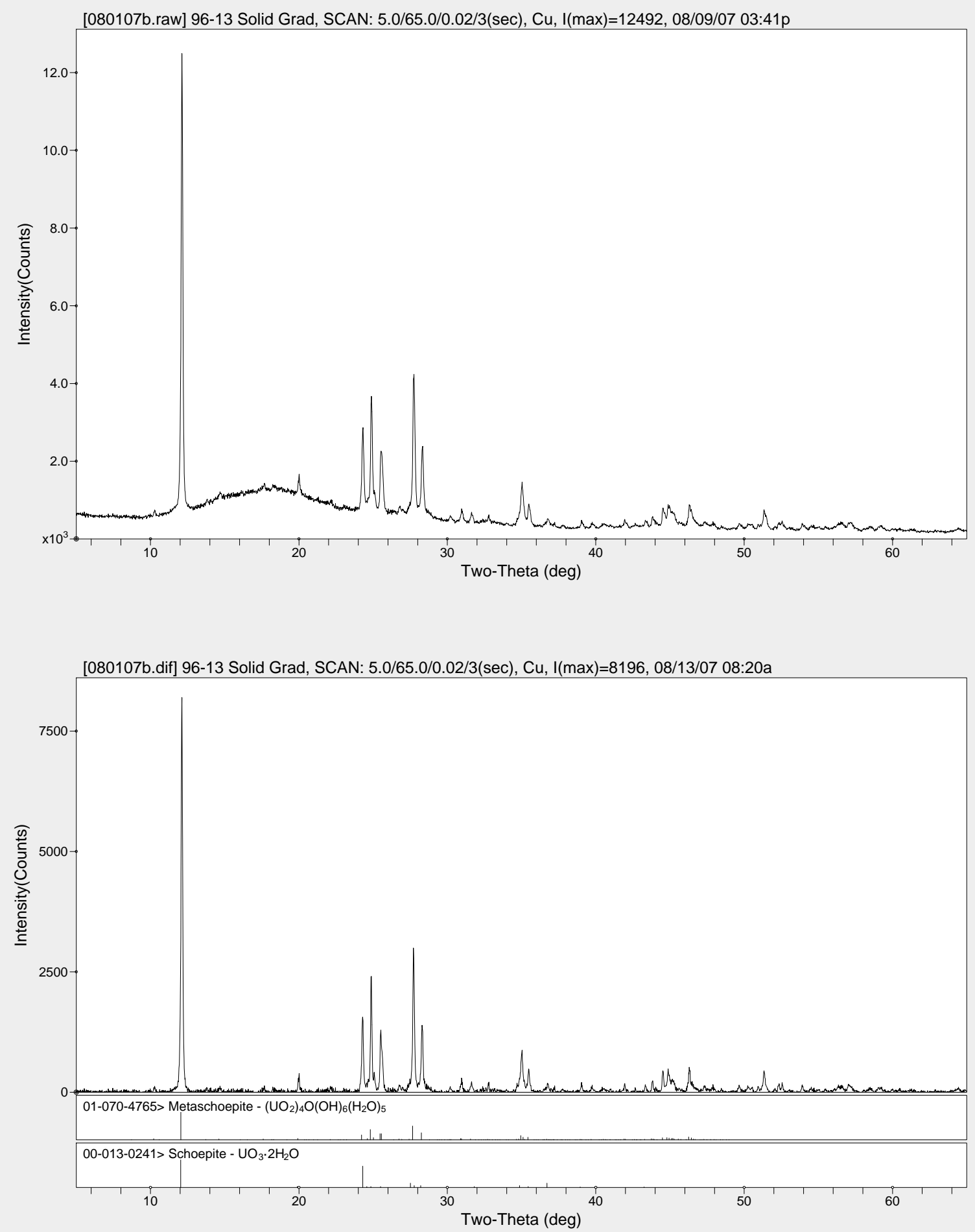

Figure B.3. Raw and Background-Corrected X-Ray Diffraction Scan for 96-13 Solid Grad 

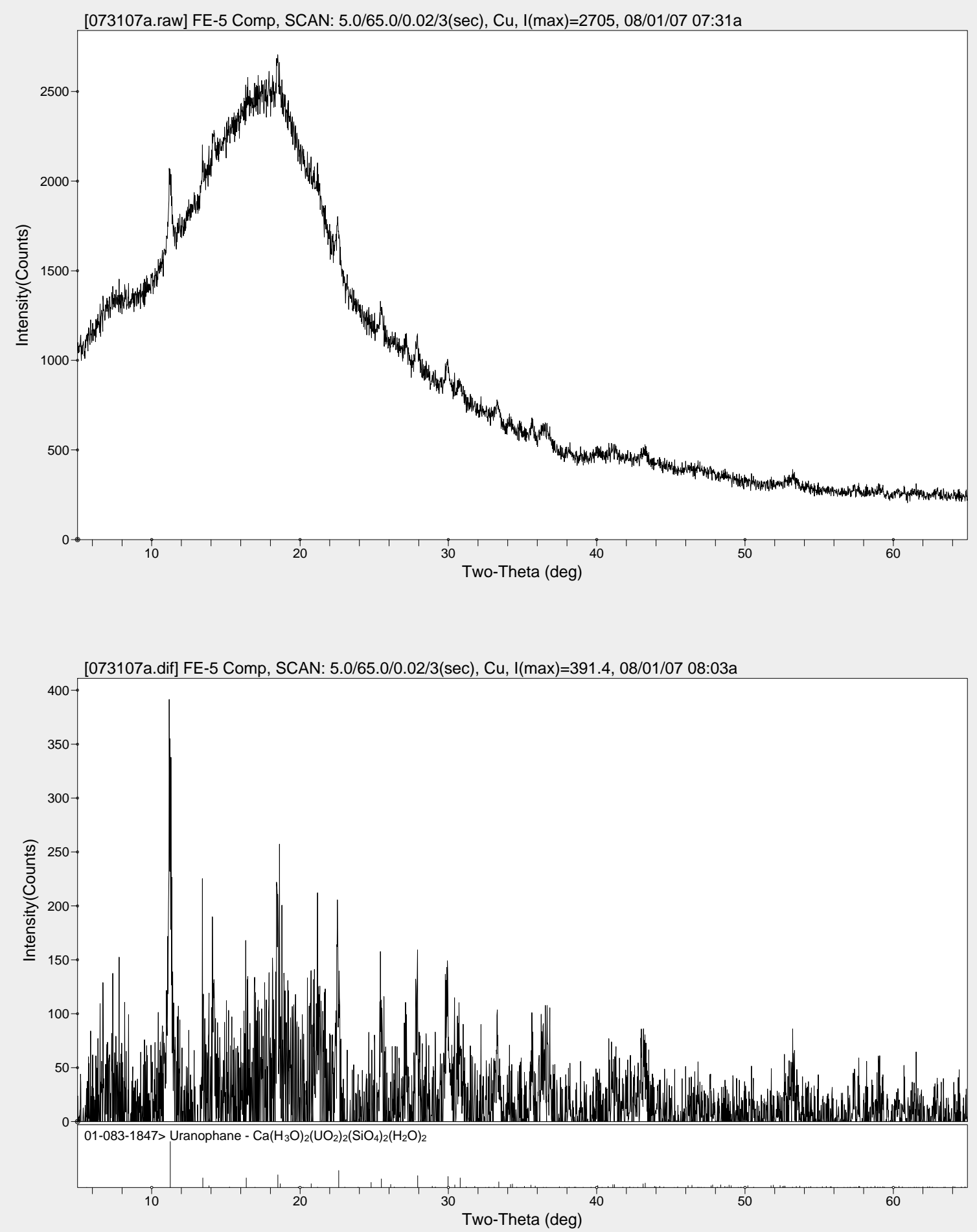

Figure B.4. Raw and Background-Corrected X-Ray Diffraction Scan for FE-5 Comp 

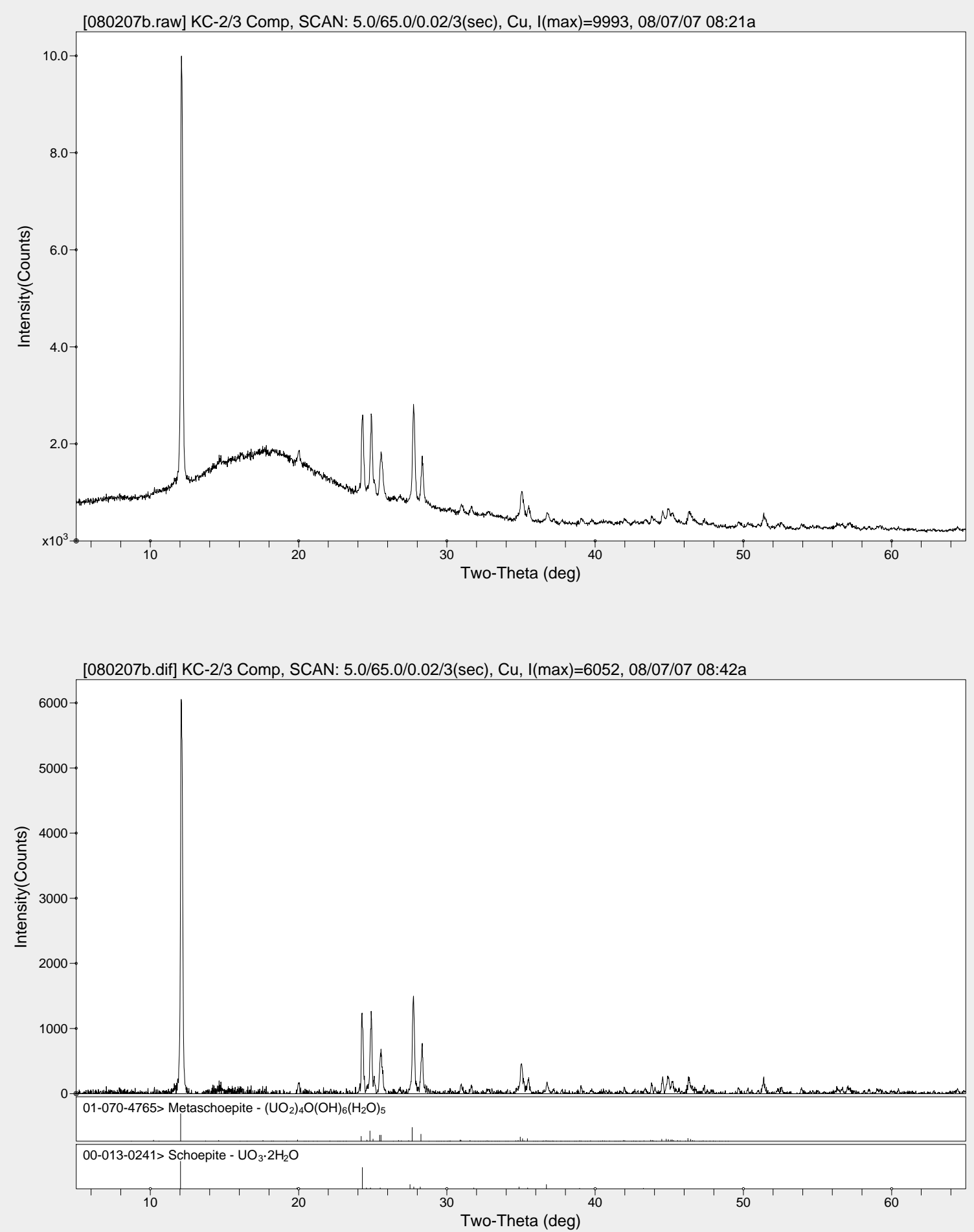

Figure B.5. Raw and Background-Corrected X-Ray Diffraction Scan for KC-2/3 Comp 

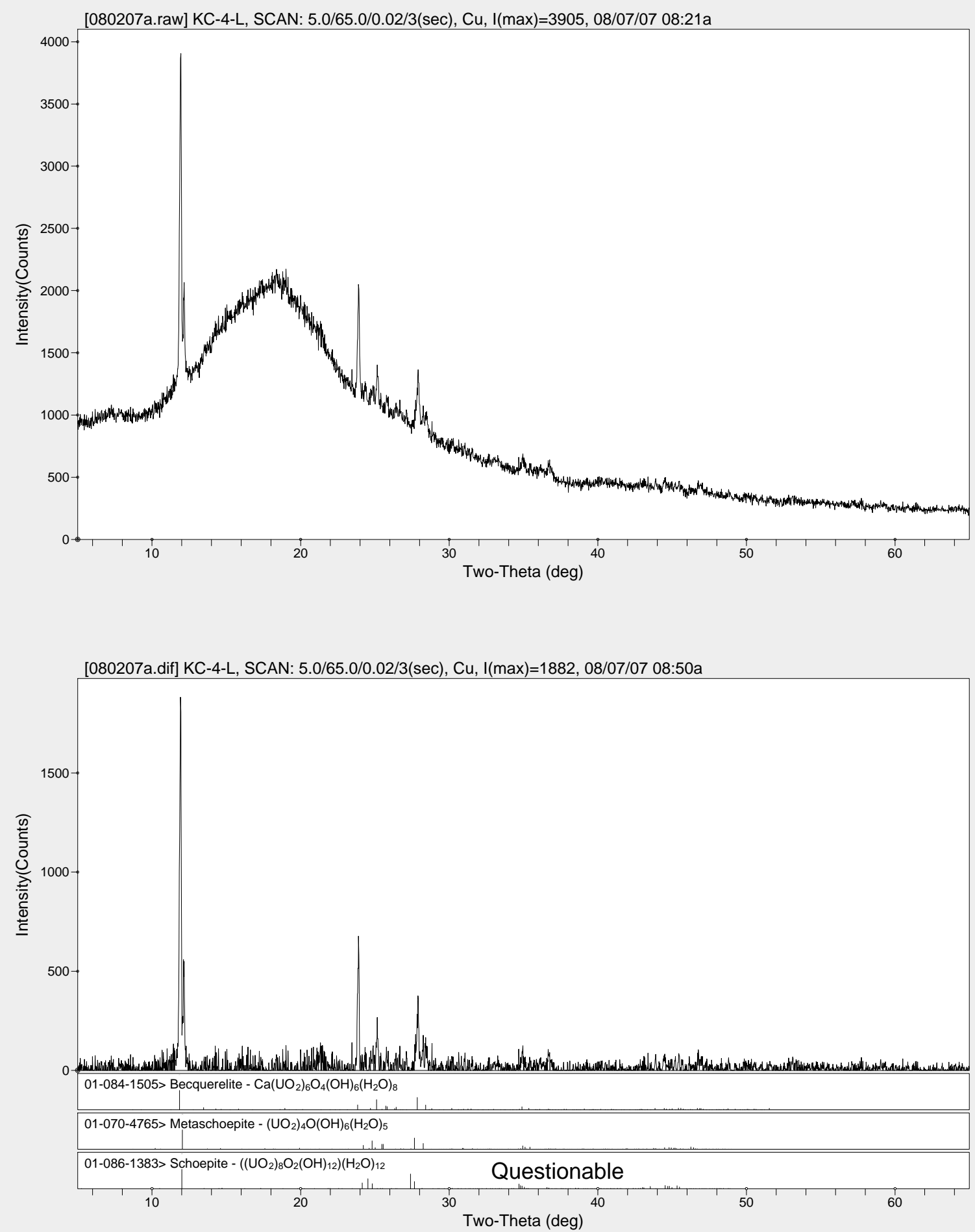

Figure B.6. Raw and Background-Corrected X-Ray Diffraction Scan for KC-4-L 

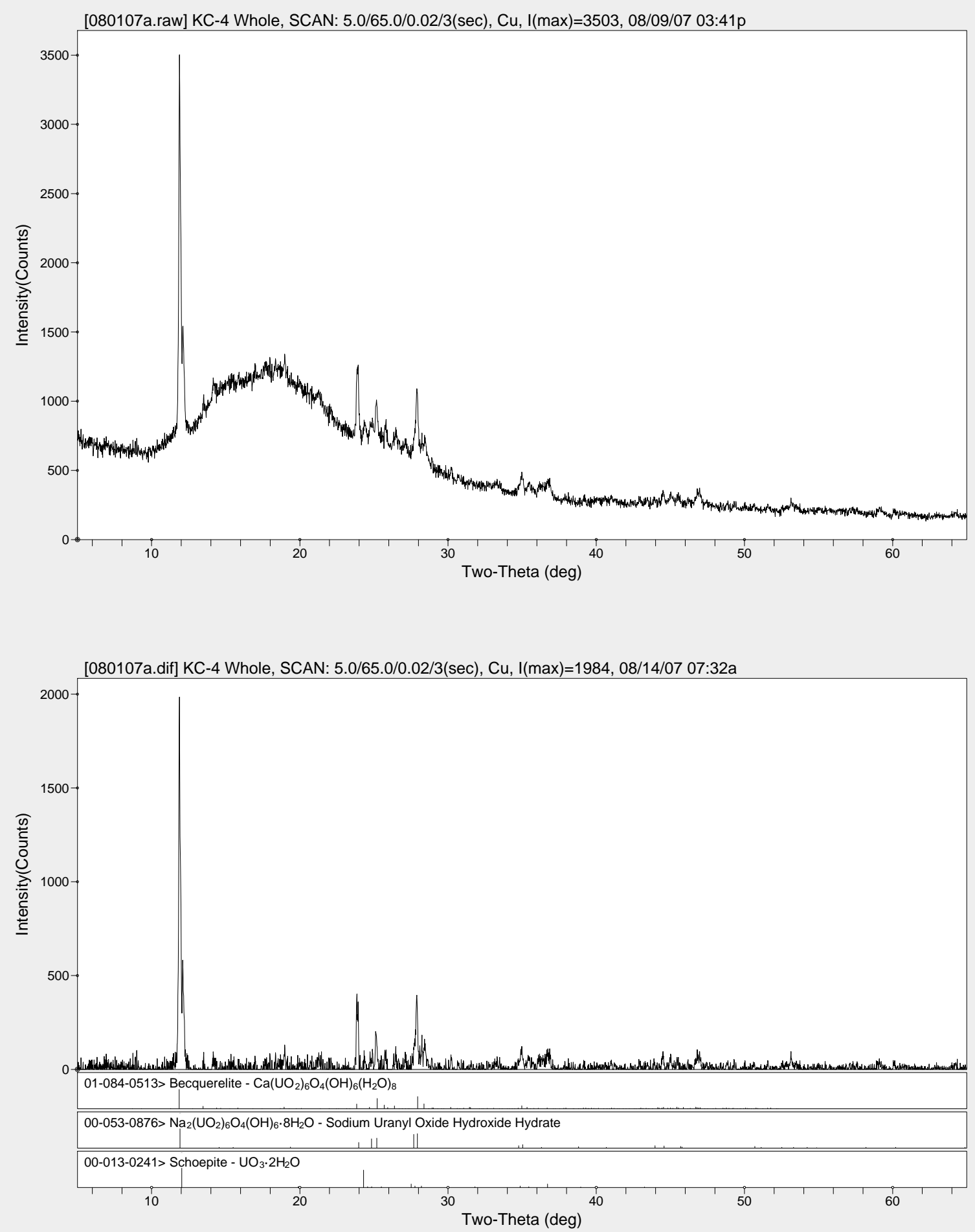

Figure B.7. Raw and Background-Corrected X-Ray Diffraction Scan for KC-4 Whole 

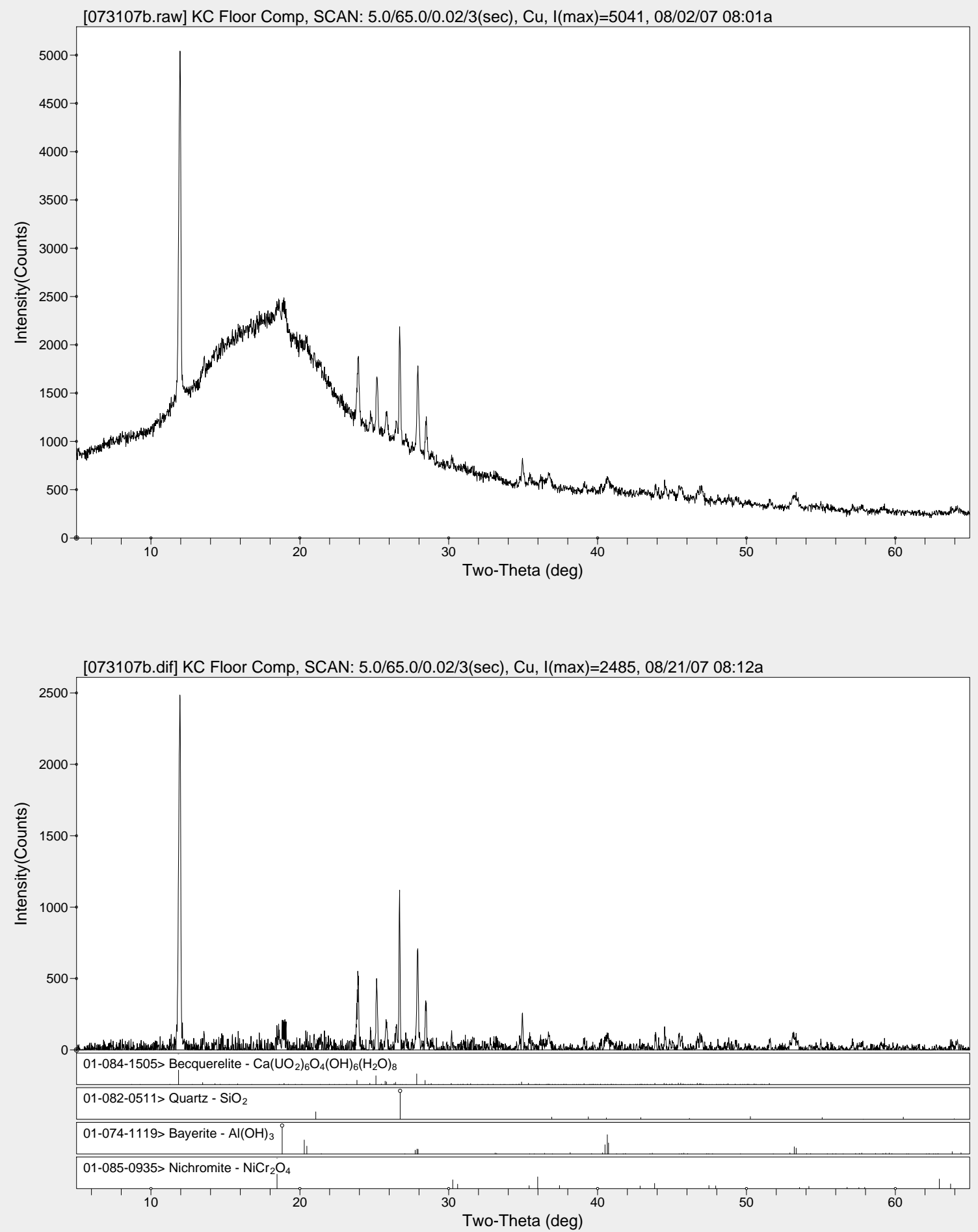

Figure B.8. Raw and Background-Corrected X-Ray Diffraction Scan for KC Floor Comp 

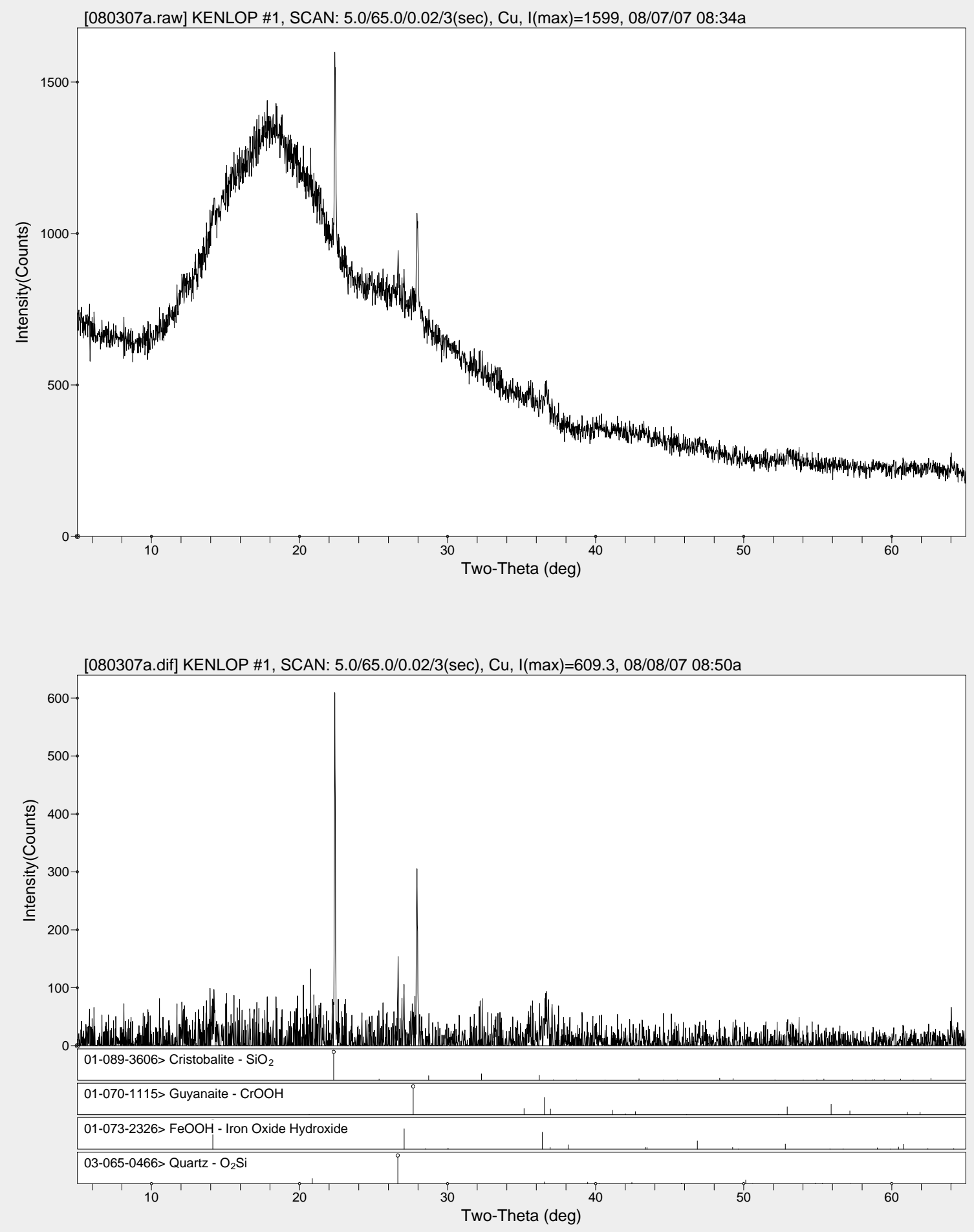

Figure B.9. Raw and Background-Corrected X-Ray Diffraction Scan for KENLOP \#1 (Jar \#1) 

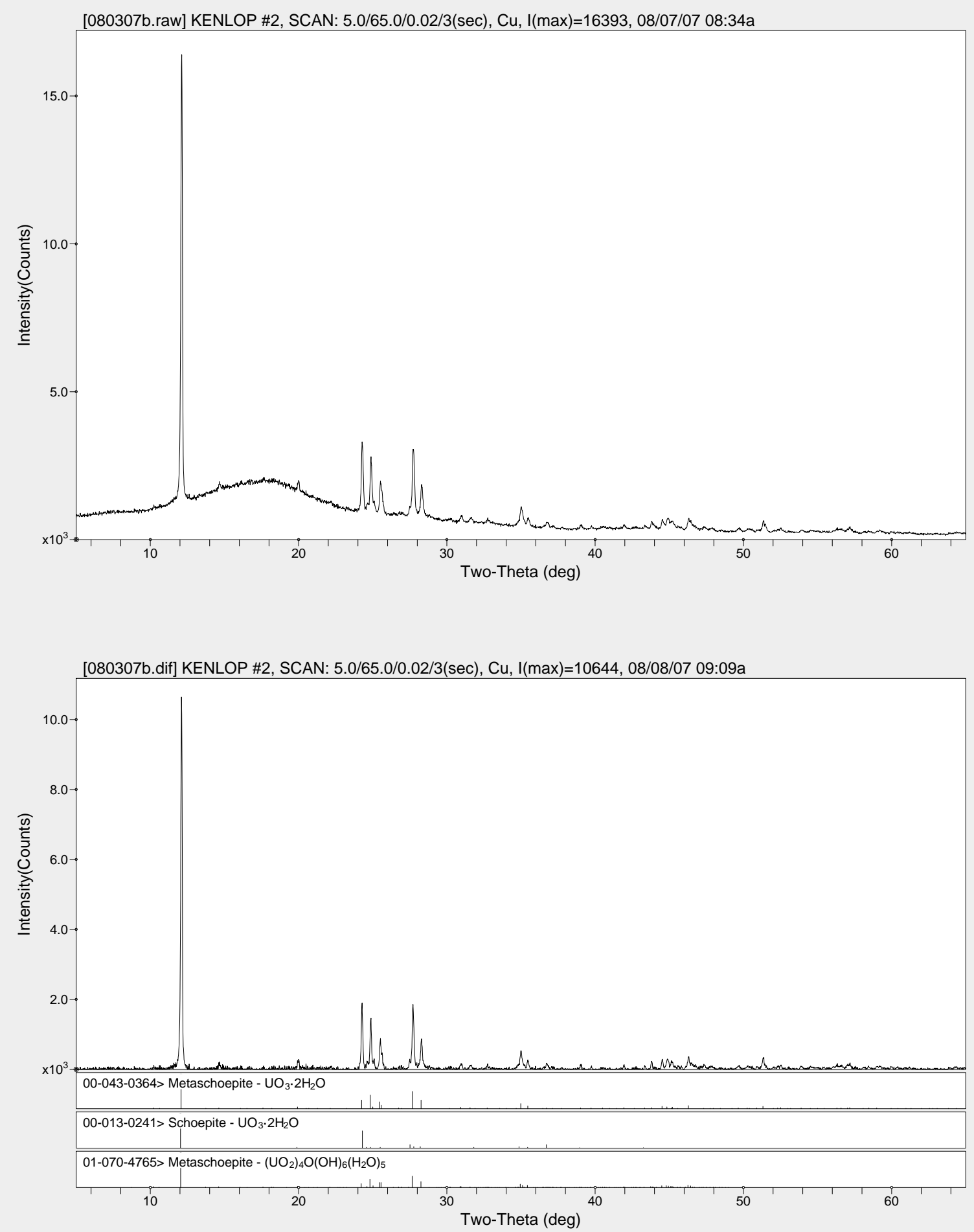

Figure B.10. Raw and Background-Corrected X-Ray Diffraction Scan for KENLOP \#2 (Jar \#3) 


\section{Distribution*}

No. of

Copies

6 CH2M Hill Plateau Remediation Company

RB Baker

JO Honeyman

ME Johnson

WW Rutherford

JP Sloughter

FE Wickstrand
No. of

Copies

$9 \quad$ Pacific Northwest National Laboratory

A3-06

A3-06

A $0-26$

A3-06

A3-06

R1-29
MM Anderson

CD Carlson

JW Chenault

$\mathrm{CH}$ Delegard

WC Dey

LM Peurrung

AJ Schmidt

FH Steen

Project File

Information Release (pdf)
P7-28

P7-25

P7 -25

P7-25

J2-56

K9-09

P8-60

P7-25

K3-52

*All distribution will be made electronically. 


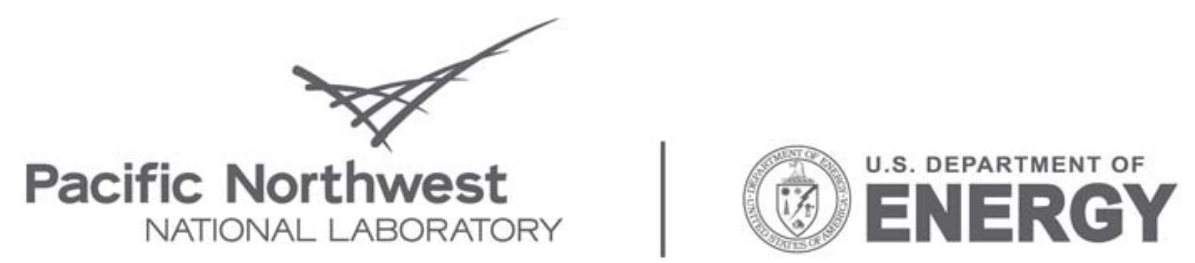

Proudly Operated by Battelle Since 1965

902 Battelle Boulevard

P.O. Box 999

Richland, WA 99352

1-888-375-PNNL (7665)

www.pnl.gov 